
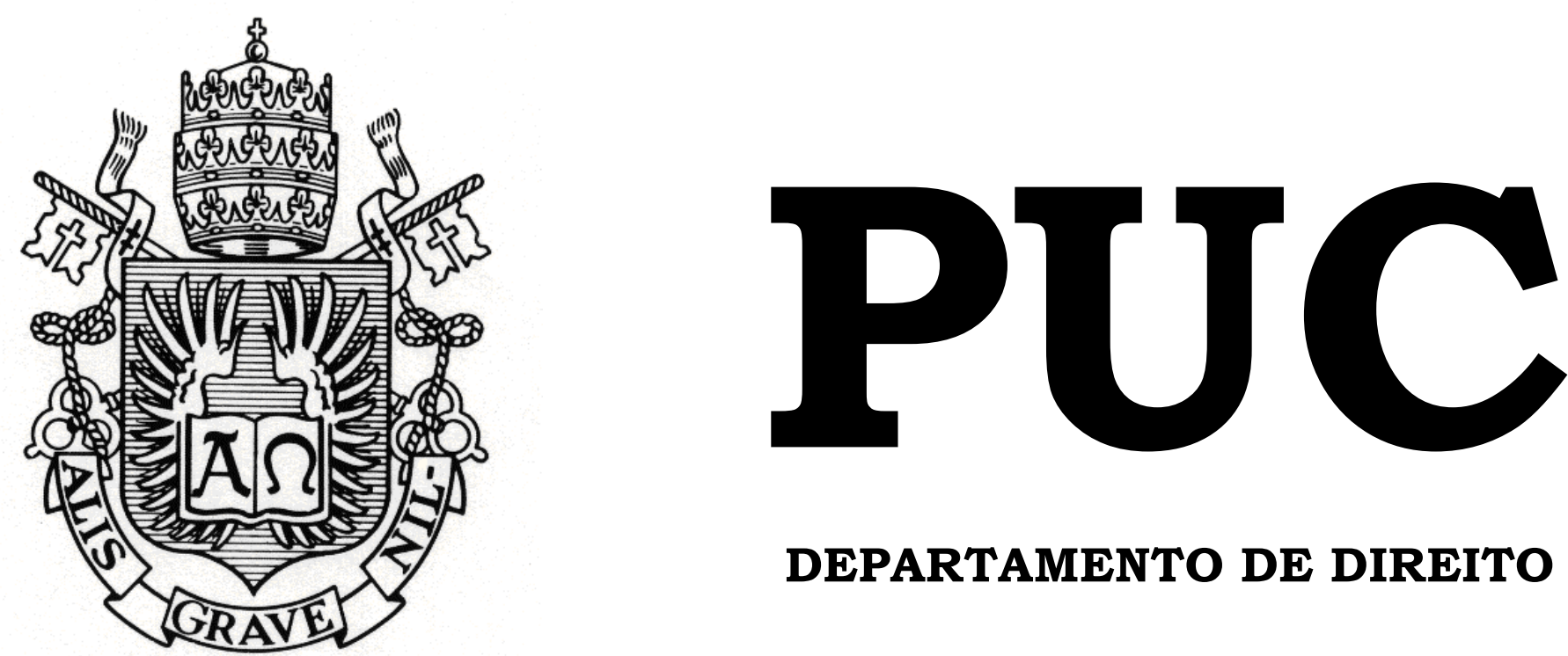

DEPARTAMENTO DE DIREITO

\title{
A origem e evolução do tribunado da plebe na Roma republicana
}

por

Priscilla Moura Del Cima

de Alvarenga Menezes

\section{ORIENTADOR: Adriano Pilatti}

2012.1

PONTIFÍCIA UNIVERSIDADE CATÓLICA DO RIO DE JANEIRO

RUA MARQUÊS DE SÃO VICENTE, 225 - CEP 22453-900

\author{
RIO DE JANEIRO - BRASIL
}




\section{A origem e evolução do tribunado da plebe na Roma republicana}

por

Priscilla Moura Del Cima de Alvarenga Menezes

Monografia apresentada ao Departamento de Direito da Pontificia Universidade Católica do Rio de Janeiro (PUC-Rio) para a obtenção do Título de Bacharel em Direito.

Orientador: Adriano Pilatti 
A meu avô, Dilson de Alvarenga Menezes 


\section{Agradecimentos}

A Dilson, meu avô, por com sua infinita sapiência enciclopédica ter me empolgado com história romana desde pequena;

A Virginia, minha mãe, por ser inacreditável, infalível e sempre presente;

A Virginia, minha avó, pelo amor e companheirismo constante;

A Bárbara, minha roommate, por ter mudado minha vida for good;

A Luc, meu Caio Mário, por seu exemplo e genialidade;

A Adriano Pilatti, meu orientador, pelo privilégio de partilhar seu conhecimento. 


\section{Resumo}

O tema do presente trabalho monográfico é a instituição do tribunado da plebe no Direito Romano. De início, é analisada a origem da distinção entre patrícios e plebeus, e as interpretações da historiografia quanto ao contexto social em que se deu, em 494 a.C. a primeira secessão da plebe romana e a criação do tribunado. Em seguida, há o exame detalhado da evolução dos poderes e direitos do tribuno da plebe durante toda a República, com foco em sua inviolabilidade, no poder de veto e na atuação junto à Assembleia da Plebe. Relata-se então a extinção temporária do tribunado sob o Decenvirato e a criação da Lei das XII Tábuas. Por fim, narra-se como o estabelecimento da nobreza patrício-plebeia após 367 a.C. alterou o cerne do tribunado, e se questiona o real papel do tribuno da plebe no declínio da República.

\section{Palavras-chave}

Tribuno da plebe - Direito Público Romano - República - Plebs Patriciado - Secessão - Veto - Assembleia da Plebe - Decenvirato - Lei das XII Tábuas - Nobilitas - Gracos. 


\section{Sumário}

Introdução

\section{Capítulo I: Patrícios e plebeus}

1. A problemática dos registros históricos $\quad 10$

2. A origem da distinção entre plebeus e patrícios 12

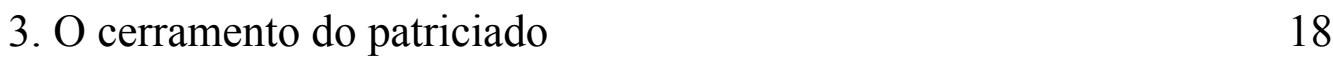

4. O advento da República 19

Capítulo II: Os poderes do tribuno da plebe

1. A primeira secessio plebis 23

2. O tribuno da plebe 26

3. Sacrosanctitas $\quad 35$

4. Intercessio $\quad 40$

5. Atuação na Assembleia da Plebe 45

Capítulo III: $O$ tribuno e a estabilidade da República

1. A Lei das XII Tábuas 55

2. A nobilitas 63

3. A emergência dos populares $\quad 67$

4. O tribuno no declínio da República 71

$\begin{array}{ll}\text { Conclusão } & 78\end{array}$

$\begin{array}{ll}\text { Bibliografia } & 81\end{array}$

$\begin{array}{ll}\text { Índice remissivo } & 85\end{array}$ 
"Nam mihi quidem pestifera videtur, quippe quae in seditione et ad seditionem nata sit."

(Cícero, De legibus, III.19) 


\section{Introdução}

A presente monografia tem como objetivo narrar a criação do instituto do tribunado da plebe na Roma republicana, e delinear os principais estágios de sua evolução.

O estudo do tribunado é de suma importância para a compreensão da história política de Roma. A ação de tribunos perpassa a maioria dos acontecimentos-chave que moldaram a República; a evolução dos poderes e direitos do tribuno corre paralela às mudanças sociais e políticas de cada século.

Segundo razoável consenso na doutrina, o tribunado se originou no início do quinto século, num ápice do conflito entre a elite patrícia e a plebs. Seus poderes essencialmente negativos confirmam o caráter de defesa de plebeus - tanto individualmente como enquanto coletividade do instituto. Nos séculos seguintes, as graduais vitórias da plebe, que em sua maioria conferiram direitos à elite plebeia e pouco ajudaram os menos favorecidos, assimilaram o tribunado à ordem constitucional romana, conferindo-lhe a função de legislador, sem lhe retirar por inteiro o status de representante do povo por excelência; o tribuno e seus poderes de provocatio e intercessio eram o mecanismo de controle mais relevante face à autoridade de magistrados e do Senado.

Pelas contradições a ele inerentes e seu explosivo papel no declínio da República, o instituto do tribunado sempre me fascinou. É sempre problemática a caracterização da República como uma democracia, pois o termo hoje abarca uma série de conceitos estranhos a Roma, onde magistrados não tinham o efetivo dever de representar seu eleitorado no exercício do mandato; onde os requisitos censitários e a prática da atuação 
nos contiones e comitia afastavam da vida pública grande parcela da população; onde mulheres e escravos eram submissos à autoridade do paterfamilias e politicamente invisíveis. Ainda assim, se se pode dizer que na ordem constitucional romana havia um elemento democrático, este encontrava voz na figura do tribuno.

É impossível estudar história romana e não se deixar tocar por admiração pela plebs revolta de 494 a.C., pelos expoentes de atividade tribunícia nos séculos seguintes que agiram contra a própria classe de nobiles a que pertenciam, pelos homines novi que se fizeram notáveis apesar da dificuldade de participar na política quando não se fazia parte das famílias tradicionais, e pelos eminentes reformadores da Roma tardia que afinal levaram à sua derrocada com suas tentativas de salvá-la.

No primeiro capítulo, fez-se necessária a óbvia ressalva preliminar quanto aos problemas da tradição analítica com que se confronta qualquer exame de história romana. Procurei delinear as principais correntes da historiografia moderna na questão da origem da distinção entre patrícios e plebeus - utilizando como base principal as obras de Niebhur, Mommsen, De Sanctis, Momigliano, De Martino e Cornell - e assim compor um panorama do contexto de conflito das ordens em que se formou a plebs que em 494 a.C. realizaria a secessio.

No segundo capítulo, relatei a importância da secessio e do reconhecimento das instituições plebeias a partir deste momento histórico. Detive-me então sobre o tribunado em si, lançando mão dos escritos de Badian, Cornell, De Martino, Lintott, von Ungern-Sternberg, Taylor, Morstein-Marx, Konrad e Gruen para descrever os direitos, poderes e limites inerentes à atividade tribunícia, a crescente importância do instituto na ordem constitucional romana e a utilização do tribunado por parte da aristocracia para manutenção de seus interesses. Em seguida, realizei uma análise detalhada dos três principais aspectos do poder tribunício: a sacrosanctitas, o veto e sua atuação na Assembleia da Plebe. 
No capítulo final, realizei um breve exame, com apoio em Eder, Mouritsen, Morstein-Marx, Cornell, von Ungern-Sternberg, Mommsen, Badian, Syme, Meier e Gruen, da atuação do tribuno nos séculos entre a secessio e a República tardia: a abolição do tribunado com o decenvirato e sua subsequente restauração, a constituição da nobreza patrício-plebeia após a conquista do direito regular ao consulado por plebeus, a emergência dos populares no segundo século a.C. e, por fim, o papel desempenhado por tribunos na crise que levaria à constituição do Principado.

O tribunado da plebe sempre me foi o tópico mais caro na história da República; espero ter conseguido fazer justiça à sua magnificência nas páginas a seguir. 


\section{Capítulo I \\ Patrícios e plebeus}

\section{A problemática dos registros históricos}

Qualquer tentativa de examinar história romana - principalmente a história da Roma real e do início da República, objeto do presente estudo — tem como principal obstáculo a falta de registros da época confiáveis. As obras dos primeiros analistas de que temos registro datam do período da Segunda Guerra Púnica (c. 200 a.C.); a data tradicional para o início da República é 509 a.C.; Tito Lívio e Dionísio de Halicarnasso, os autores com registros mais compreensivos sobre a fase em tela, laboraram em suas obras nas últimas décadas a.C., cinco séculos após os eventos narrados.

Os historiadores clássicos certamente tinham acesso a hoje desaparecidos registros, monumentos e tradição oral, bem como obras de estudiosos anteriores. No entanto, é evidente que trabalhavam com critérios diferentes dos que hoje entendemos como relevantes ou corretos; os dados que registraram frequentemente não sobrevivem ao escrutínio da historiografia moderna ${ }^{1}$. Em particular, a descrição com flagrantes traços míticos dos lendários sete reis de Roma decerto é quase por inteiro fabricada, com laços tênues com figuras existentes ${ }^{2}$.

Por séculos, porém, os poucos escritos sobreviventes foram tidos como verdade absoluta, descartando-se somente os mais gritantes exageros mitológicos, como as origens de Rômulo. Porém, principalmente, a partir do século XVIII, romanistas passaram a reexaminar criticamente o conteúdo dos anais. Verifica-se com facilidade a extensão com que eventos políticos posteriores afetaram narrativas mais antigas; é inegável, por

\footnotetext{
${ }^{1}$ Para um relato mais detalhado das fontes históricas do Direito Romano e da evolução de seu estudo, vide Momigliano, 1963, pp. 96ss.

${ }^{2}$ Forsythe, 2005, pp. 87ss.; Raaflaub, 2006, loc. 2180.
} 
exemplo, que as tentativas de reforma dos Gracos (133-121 a.C.) e a oposição de populares e optimates da República tardia informam relatos de atividade tribunícia séculos antes de sua ocorrência ${ }^{3}$. O exame da obra de um historiador romano revela tanto sobre a memória política dos séculos que o precederam do que sobre o período que narra.

O fervor metodológico levou a um severo questionamento do valor historiográfico da tradição analítica, buscando considerar somente os fatos básicos, "autênticos", ignorando a "superestrutura narrativa". 4 Alguns avanços arqueológicos, contudo, vieram a corroborar em parte a narrativa preservada. ${ }^{5}$ Prevalece atualmente uma posição mais moderada: por um lado, alguns romanistas apontam o inegável valor literário das obras dos analistas, defendendo que sejam examinados com a cautela conferida ao estudo histórico da Ilíada e outras obras-primas clássicas; por outro, ressalta-se a importância do estudo comparado com outras civilizações da época, dos registros arqueológicos e do confronto com a história romana posterior, da qual temos fontes em maior abundância, para a investigação cautelosa da narrativa histórica por trás das obras dos analistas clássicos ${ }^{6}$.

Para a História do Direito, todavia, mesmo os registros questionáveis de Lívio e seus contemporâneos em sua íntegra têm indubitável valor intrínseco: afinal, eles refletem o que os romanos da época acreditavam ser sua história. Roma não tinha constituição escrita; seu Direito Público, mais ainda do que o Privado, era ferrenhamente ancorado em costumes: o mos maiorum.

Lintott, ao se debruçar sobre o estudo do Direito constitucional romano, observa:

\footnotetext{
${ }^{3}$ Cornell, 2005, p. 60. Para um relato da projeção de inovações tribunícias da República tardia nos séculos anteriores pela tradição analítica, vide David, 1993, pp. 58ss.

4 Bringmann, por exemplo, ao estudar o início da República, rejeita quase integralmente a narrativa analítica do período (Bringmann, 2007, pp. 37ss.). Vide também Raaflaub, 2006, loc. 2303ss..

${ }^{5}$ Momigliano, 1963, p. 106; Forsythe, 2005, pp. 100ss..

${ }^{6}$ Momigliano, 2005, pp. 170ss.; Raaflaub, 2005a, pp. 5ss.
} 
"The constitution of the Republic consisted of far more than statutes: it was based on traditional institutions defined by precedents and examples. These were above all embodied in stories, whether these related to more recent events and had good claims to historicity or were reconstructions of distant events with a strong element of myth. Thus the constitution did not stand above politics like a law-code: it is what the Romans thought to be right and did, and in more senses than one it was a product of history."

O presente capítulo busca investigar, em meio às disputas sobre a verdade histórica das narrativas da Realeza e do início da República, a conjuntura sócio-política que levou à criação do tribunado da plebe.

\section{A origem da distinção entre plebeus e patrícios}

A instituição do tribunado da plebe está no cerne da disputa entre a plebe e o patriciado. A caracterização de tal disputa e a definição da origem das duas ordens é um indispensável ponto de partida para a compreensão do instituto; trata-se de uma questão de particular controvérsia. Não há consenso sobre quando tal separação teria se iniciado. A data tradicionalmente utilizada como marco do início do conflito entre as ordens — 494 a.C., ano em que ocorreu a primeira secessio plebis — obviamente denota um ápice de tensões sociais que há tempos se acumulavam.

O estudo da origem do conflito das ordens é especialmente dificultado por serem todas as obras a que temos acesso escritas após a resolução do mesmo. Os historiadores de eras posteriores não tinham dimensão alguma de como teria sido a organização social da Roma de dois séculos antes ${ }^{8}$; não questionaram, por exemplo, que não eram estáticos a composição da população romana, as demandas e mazelas das camadas mais pobres da sociedade, o balanço de poder entre o Senado, as magistraturas e as assembleias, o desenvolvimento do exército, e a evolução

\footnotetext{
${ }^{7}$ Lintott, 1999, p. 26

8 "It is clear that in the third century B.C. no one had any clear idea of what Roman society had been like in the first half of the fifth century. (...) It was far easier for them to assume that the plebs and the patriciate of 500 B.C. were much the same as the plebs and the patriciate of 200 B.C. (...) For these annalists the struggles between the patricians and the plebeians in the fifth century naturally appeared to be the same as the conflicts of the time of Gaius Gracchus and Sulla." (Momigliano, 2005, p. 169.)
} 
dos princípios legais como a libertas $^{9}$. Subsistiam relatos das principais conquistas da plebe, e registros de como haviam sido alcançadas, sem grandes elucubrações sobre as causas de cada evento; além disso, os romanos tinham as tradições vivas do tribunado e da provocatio, inegáveis testemunhos do adormecido conflito, e, no dizer de Lintott, a narrativa analítica que daí emergiu foi uma tentativa galante de fazer jus a tais dados ${ }^{10}$.

O primeiro registro da distinção legal entre as duas ordens é a proibição de casamento entre patrícios e plebeus (ius conubii), cuja inserção na Lei das XII Tábuas é narrada como inhumanissima lex por Cícero ${ }^{11}$; todos os relatos do evento deixam claro que a proibição foi uma inovação por parte dos decênviros ${ }^{12}$. A constituição das duas ordens é, portanto, anterior a este momento; mas não há tentativa de maior precisão que tenha restado incontestada na doutrina.

A explicação que Lívio, Dionísio e Plutarco oferecem para a separação entre as duas ordens - uma divisão artificial efetuada por Rômulo, primeiro rei de Roma - é, como aponta De Martino, ingênua e inútil, posto que ignora por inteiro o complexo processo social, econômico e político da formação das classes ${ }^{13}$. Cumpre aos romanistas, portanto, a tentativa de vislumbrar nas entrelinhas da historiografia sobrevivente as causas e origens da divisão da sociedade romana entre patrícios e plebeus.

$\mathrm{O}$ primeiro grande esforço teórico crítico neste sentido foi o de Niebuhr, que propôs a plebe ter sido uma comunidade de agricultores livres com organização, religião e Direito independentes das três tribos patrícias, com sede no Aventino e no Esquilino, constituída por habitantes das regiões vizinhas a Roma e, com o passar do tempo, por imigrantes. Sérvio Túlio,

\footnotetext{
${ }^{9}$ Raaflaub, 2005a, p. 11.

10 Lintott, 1999, p. 39.

${ }^{11}$ Cícero, De re publica, II, 63 (2006, p. 84).

${ }^{12}$ Last, 1945, pp. 31-32.

${ }^{13}$ De Martino, 1972, p. 65.
} 
monarca plebeu, teria organizado a plebe em trinta tribos, às quais posteriormente foram adicionados os patrícios e seus clientes ${ }^{14}$. Outros autores, como Grosso e Arangio-Ruiz, defendem a compreensão da plebe como organização separada da Roma patrícia, frisando as diferenças de religião e de costume como prova e a ameaça de secessão em 494 a.C. como demonstração do potencial de auto-organização da comunidade plebeia $^{15}$

Já Mommsen sustentou terem sido os plebeus originalmente imigrantes, artesãos ou comerciantes, clientes do rex ou dos patrícios (os quais compunham as três tribos originais). Com o enfraquecimento dos laços de clientela, a falta de direitos políticos dos plebeus foi se tornando cada vez mais evidente, e somente a sujeição igual de todos ao rex impediu o estourar de conflitos entre as ordens ${ }^{16}$. No entanto, a tradição analítica é constante ao retratar a clientela apoiando os patrícios na resistência às reivindicações plebeias $^{17}$; numericamente, o patriciado não poderia ter contingente para fazer frente aos plebeus na jovem República sem o apoio dos clientes ${ }^{18}$.

Há também diversas teorias fundadas em diferenças étnicas, hoje desacreditadas por sua multiplicidade, pela falta de fundamento probatório e por suas contradições internas ${ }^{19}$.

Todos os autores acima defendem que, inicialmente, só os patrícios eram cidadãos romanos ${ }^{20}$. Tal tese encontra relevante obstáculo no silêncio unânime das fontes históricas quanto a reivindicações da plebe pelo direito

\footnotetext{
${ }^{14}$ Niebhur, 1827, pp. 252-3.

15 Grosso, 1965, p. 82; Arangio-Ruiz, 2006, 43ss.

${ }^{16}$ Mommsen, 1894a, p. 114.

17 De Martino, 1972, p. 72. Para um questionamento da relevância da clientela em séculos posteriores e a hipótese de que com o tempo clientes deixaram de dever a seus patronos apoio político, vide Mouritsen, 2001, loc. 51ss.

18 Momigliano, 2005, p. 175.

${ }^{19}$ De Martino, pp. 73, 76-79; Cornell, 1995, pp. 243-4.

20 Como frisa Arangio-Ruiz, "con ogni probabilità la plebe non fu esclusa dai diritti politici, anzi fece parte e delle tribù originarie e del comizio curiato e delle successive organizzazioni repubblicane: politicamente, fu esclusa soltanto dai posti di comando, cioè dalle magistrature, dai sacerdozi, dal Senato." (2006, p. 45)
} 
de voto nos comitia curiata, as primeiras assembleias constituídas por cidadãos romanos na época da realeza ${ }^{21}$.

Também é notável a ausência de conflito pela admissão de plebeus no Senado, o que levou muitos romanistas à conclusão, hoje prevalecente, de que também ele não era exclusivamente patrício ${ }^{22}$. Ademais, o fato de quatro dos lendários reis romanos terem nomes plebeus e a afirmação de Lívio que Numa, Sérvio Túlio e Tarquínio Prisco ${ }^{23}$ eram de origem plebeia $^{24}$ induziu muitos historiadores a concluir que $a b$ initio a sociedade romana era composta por patrícios e plebeus, divididos sobretudo por riqueza ${ }^{25}$.

A principal distinção entre as duas classes, entende a doutrina tradicional, seria a participação no Senado: reza a tradição que a raiz do nome patricii é a antiga denominação dos primeiros senadores, chefes dos mais poderosos clãs, como patres. Os patrícios seriam, assim, os patres e seus descendentes. Relevante também é a exclusão de plebeus de cargos sacerdotais romanos 26 ; os postos sacerdotais mais arcaicos, como os flâmines, viriam a ser o último reduto de privilégio patrício na República.

\footnotetext{
${ }^{21}$ Momigliano, 1963, p. 112: "the Curiae are elements of a State in which the gentes were not yet divided into two clear-cut groups, patricians and plebeians." Neste sentido também Richard, 2005, pp. 108 ss.

De Martino defende a historiografia silente com a tese de que o crescimento numérico da plebe na era da realeza não foi tão significativo quanto na República; ademais, as condições econômicas eram melhores antes da crise do século V; e finalmente, a dominação etrusca era menos opressora em relação à plebe do que o governo do patriciado que lhe seguiu (De Martino, 1972, p. 81)

22 Cornell, 1995, pp. 246-7; Momigliano, 1963, p. 117; vide também a seção posterior sobre a serrata del patriziato.

${ }^{23}$ Sobre a influência etrusca em Roma e a caracterização dos Tarquínios como reis etruscos, cujo exame não cabe no escopo da investigação em tela, vide: Mommsen, 1894a, pp. 150-161; De Martino, 1972, pp. 85-94; Grosso, 1965, pp. 51-56; Arangio-Ruiz, 2006, pp. 15-24; e, em sentido oposto: "The Myth of 'Etruscan Rome"” (Cornell, 1995, pp. 151-172).

24 Para Cornell (1995, pp. 142-3), a eleição de reis plebeus e imigrantes indica que patrícios não eram elegíveis para o cargo de rex, e que a escolha de "outsiders" ajudava a manter o equilíbrio das tensões entre facções da aristocracia romana.

25 Arangio-Ruiz, 2006, p. 45; Last, 1945, pp. 31ss.; Cornell, 1995, p. 251.

26 Para uma interpretação radical do conflito entre as ordens da forma que o conhecemos como inexistente - a distinção entre patrícios e plebeus seria puramente religiosa e legal, e a leitura das disputas políticas dos séculos em tela como dela resultante reflete uma compreensão faltosa da ordem social na Roma arcaica — vide Mitchell, 2005, pp. 128-167.
} 
Momigliano aponta que o monopólio da autoridade religiosa e de direitos a ela conexos, como os auspícios e a gestão do interrex, foram as principais conquistas do patriciado na época da realeza. Com o fim desta, as famílias patrícias estavam em posição ideal — haja vista a intrínseca ligação entre a religião estatal e o Direito em Roma — para consolidar seu poder político ${ }^{27}$.

Ele concorda que era possível para plebeus se tornarem senadores, e sustenta que privilégio do patriciado nesta seara era o direito hereditário à participação no Senado; neste sentido também Richard, que nota que o termo patricius, relativo a tal aspiração à hereditariedade, provavelmente se referia a linhagens, e não a indivíduos; e que só mais tarde a ideia de filiação foi eclipsada pela de vocação e prestígio no concernente à admissão ao Senado ${ }^{28}$.

É necessário notar que, enfrentando a doutrina tradicional até então estabelecida, Momigliano contestou a ideia de que o patriciado formava a cavalaria do exército romano e a plebe, a infantaria ${ }^{29}$. Os plebeus, para Momigliano, seriam os infra classem: artesãos, mercadores e pequenos

\footnotetext{
${ }^{27}$ Momigliano, 1963, pp. 112-118.

28 Richard, 2005, pp. 111ss.

${ }^{29}$ É questão de particular curiosidade por que o conflito das ordens jamais resultou em luta armada entre o patriciado e a plebs: não há registro de uma batalha sequer.

Momigliano defende que a plebe então não fazia parte do populus (isto é: da infantaria, que seria composta por clientes), exceto em situações de emergência; e oferece como prova o fato de a organização da plebe após a secessio ter sido flagrantemente não militar, apesar da evidente facilidade de transpor e adaptar o modelo da organização político-militar patrícia, e de a própria insurgência da plebe ter sido não violenta, muito embora a cavalaria no exército arcaico correspondesse a somente um décimo da infantaria. Nota ele: "The plebeians refused to obey the patricians, but they did not do battle with them. Unless human nature has changed since the fifth century B.C., the only possible explanation of this fact is that the plebs were able to cause serious embarrassment to the patricians by their disobedience, but were not adequately equipped to confront them in battle." (Momigliano, 2005, pp. 174ss.)

Cornell também sustenta que a plebs que efetuou a secessio não era composta de hoplitas, e sim de integrantes da infra classem, a qual proveria as unidades de apoio que mais tarde comporiam a quarta e quinta classes. "If the First Secession had been an uprising by the hoplite infantry, the conflict of the orders would not have lasted two days, let alone two centuries." (Cornell, 1995, p. 257)

Para Raaflaub, o fato de o conflito das ordens não ter gerado uma guerra civil que provavelmente enfraqueceria Roma a um grau letal se deve ao contexto de constantes pressões externas em que a cidade se formou. $\mathrm{O}$ povo romano em muito valorava o serviço à comunidade, a disciplina e a solidariedade contra ameaças externas, a despeito de eventuais discórdias internas (Raaflaub, 2006, loc. 2421).
} 
agricultores pobres demais para arcar com o armamento necessário para a guerra. A evolução econômica e institucional da plebs fez com que membros desta começassem a ter condições financeiras de fazer parte da infantaria, e atraiu como aliados senadores de origem plebeia e clientes descontentes com o patriciado.

Nota Cornell que o problema fundamental de equacionar patres com a elite patrícia senatorial é que patres é a palavra utilizada por todas as fontes romanas para designar patrícios, senadores ou não. Para ele, a compreensão do Senado em Momigliano como órgão de composição vitalícia e hereditária encontra claro obstáculo na lectio senatus, procedimento pelo qual o rex (e, durante a República, os censores) escolhia quem faria parte do Senado ${ }^{30}$.

Quanto ao conflito entre patrícios e plebeus, Cornell ressalta a importância da distinção entre o conceito negativo de plebs (leia-se: os nãopatrícios) e a formação da entidade política plebs, que viria a realizar a secessio. A formação da plebs qua plebs — ou seja, plebs em sentido estrito — é em muito posterior à do patriciado, e deve ser datada a partir da realização da referida secessio, em 494 a.C., medida de desespero e notável coragem da parte dos plebeus mais pobres. Dividir o povo romano simplesmente entre plebeus e patrícios é ignorar a complexa rede de laços econômicos, sociais e militares entre categorias como patres e conscripti, classis e infra classem, equites e pedites, adsidui e proletarii na época; nem todos os plebeus fizeram parte, ou sequer apoiaram, a secessio. No dizer de Cornell:

"[P]atres and plebs were at opposite ends of a complex social hierarchy, and were separated by intermediate groups who could themselves be variously classified and differentiated. The plebs were opposed not just by the patricians, but by those who had a vested interest in maintaining the status quo, including

30 Cornell defende a interpretação do Senado como mero órgão consultivo ad hoc durante a realeza; seu poder como retratado no declínio da República só seria firmado no fim do quarto século. A historiografia contemporânea teria sido prejudicada pela presunção inconteste de que o Senado sempre havia sido o órgão de maior poder em Roma. (1995, pp. 246-250.) Nota-se que Raaflaub nega que a lectio senatus tenha origem na Roma real; sua função pressupõe uma elite abastada não-senatorial e Raaflaub nega a existência desta na jovem República $(2005$, p. 187). 
the farmers who formed the hoplite phalanx, and those well-to-do persons who, although not of patrician status, nevertheless managed to reach the consulship in the early Republic. To call these men plebeians, in the circumstances of the years before and after $500 \mathrm{BC}$, would be quite mistaken." 31

\section{O cerramento do patriciado}

A concepção de um Senado com membros de origem plebeia leva a um questionamento: se a elite plebeia tinha acesso à participação política no início da República — os polêmicos fasti consulares arrolam como cônsules dezesseis nomes de gentes tradicionalmente plebeias entre 509 e 445 a.C. ${ }^{32}$ - por que se fez necessária, um século depois do início da República, a luta pelo acesso da plebe às magistraturas?

De Sanctis criou uma tese, amplamente recepcionada, sobre o que denomina "la serrata del patriziato". Segundo ele, a lectio senatus permitiu que os reis de Roma incluíssem plebeus e imigrantes entre os senadores. Após o advento da República, o patriciado, buscando garantir seus privilégios e se afirmar como elite governante frente às demandas da plebs que se organizava, cerrou fileiras, e deixou de admitir a entrada de plebeus na aristocracia. A proibição do casamento entre patrícios e plebeus foi um marco de tal processo: uma tentativa flagrante do patriciado se conservar inteiramente separado dos demais cidadãos romanos ${ }^{33}$. Nota Torelli:

\footnotetext{
31 Cornell, 1995, p. 258.

32 Os fasti consulares - a lista de cônsules de todos os anos, desde a data tradicional para a fundação da República — são exaustivamente discutidos pela doutrina romanista. É um eufemismo dizer que a credibilidade da lista, indubitavelmente composta a posteriori, quanto aos magistrados no primeiro século é duvidosa. A presença dos referidos nomes de gentes tradicionalmente plebeias - a começar por Lúcio Júnio Bruto, dito fundador da República numa época em que, rezam os anais, só patrícios tinham acesso ao consulado, exigiu da doutrina explicações das mais variadas para justificar a tradição: por exemplo, talvez as gentes em questão tenham sido outrora patrícias, e ou se submeteram à transitio ad plebem, ou morreram e outra gens com o mesmo nome foi formada pelos descendentes de seus libertos; ou talvez famílias de renome tenham engendrado a inserção nos fasti de um ancestral para aumentar seu prestígio (muito embora, como observa Develin (2005, p. 296), famílias demais tinham interesse na lista para permitir falsificações em muito grande escala). É impossível traçar nestas breves linhas um panorama completo das discussões sobre o tema. Vide Cornell, 1995, 252-256 e 336-7; Raaflaub, 2005, pp. 187ss. Linderski, 2005, 226ss.; Develin, 2005, 293ss.; Momigliano, 1963, pp. 103ss.; Forsythe pp. 160ss et al..

${ }^{33}$ De Sanctis, 1907, pp. 232ss.
} 
"This was an oligarchic decision that took the form of an absolute rejection of every type of social mobility, both horizontal - which until that time had been sustained by the entry of foreign clans into the local aristocracies - as well as vertical, which consequently excluded the citizens of the lower classes from political life." 34

Cornell aceita a hipótese de serrata, interpretando-a como o gradual estabelecimento do monopólio de patrícios sobre as magistraturas, utilizando como fundamento o marcado decréscimo de nomes de gentes plebeias nas principais magistraturas com o passar das primeiras décadas da República $^{35}$.

Segundo Forsythe, a serrata se deu nas últimas três décadas do quinto século. $\mathrm{O}$ último ano em que há nos fasti registro de um cônsul de nome plebeu antes de 367 a.C. (quando plebeus reconquistaram o direito ao consulado) é 423 a.C. ${ }^{36}$.

A aceitação da serrata na doutrina romanista não é unânime. Raaflaub rejeita a ideia de uma elite plebeia neste período, apontando que, caso existisse um grupo de plebeus abastados e excluídos do governo de Roma, o caráter e a direção do conflito das ordens em suas fases iniciais teria sido muito diferente do que o que se demonstrou na secessio ${ }^{37}$.

\section{O advento da República}

Segundo a tradição histórica romana, o tirânico último rei de Roma, Tarquínio, o Soberbo, teria sido derrubado em cerca de 500 a.C. ${ }^{38}$ por um movimento revolucionário aristocrático liderado por Lúcio Júnio Bruto ${ }^{39}$, cujo estopim teria sido o estupro da jovem Lucrécia pelo filho do tirano.

\footnotetext{
34 Torelli, 2006, loc. 1535.

35 Cornell, 1995, pp. 252ss.

36 Forsythe, 2005, pp. 165ss.

37 Raaflaub, 2005, pp. 199ss.

38 Sobre a problemática cronologia do início da República, vide Cornell, 1995, pp. 218ss.

39 Os Junii, aliás, eram uma gens plebeia de grande prestígio na República tardia; Bruto era, muito provavelmente, também plebeu. O célebre Marco Júnio Bruto, assassino de Caio Júlio César, muito orgulhava-se de ser descendente direto do fundador da República (Cassius Dio, 44.12).
} 
Bruto se tornaria o primeiro cônsul da nascente República, junto com Lúcio Tarquínio Colatino.

A narrativa clássica, que tem clara influência grega ${ }^{40}$, é por inteiro questionada pela doutrina romanista contemporânea. Como Forsythe observa, a teoria constitucional e a historiografia frequentemente agem na sequência de uma grande mudança sócio-política para construir sistemas ordenados com transições lógicas que não correspondem à realidade, e o mesmo deve ter ocorrido com o advento da República ${ }^{41}$.

Há inclusive quem entenda não ter havido revolução alguma, e sim um lento declínio da monarquia ${ }^{42}$, levando à gradual evolução do sistema de governo, notadamente Gjerstad e De Sanctis. O rex teria sido aos poucos relegado, com a denominação rex sacrorum, à esfera religiosa (reductio ad sacra), na qual subsistiu — sem poder político algum, mas com grande prestígio tradicional - até o Império ${ }^{43}$. Tal hipótese, fundada na comparação com o archon basileus ateniense, é controversa ${ }^{44}$. Para Momigliano, o cargo de rex sacrorum teria coexistido com o rex, ou sido criado para suprir na esfera religiosa a ausência deste, consoante o relato de Tito Lívio ${ }^{45}$.

Cumpre notar que no período da República qualquer pretensão ao cargo de rei de Roma era encarada com ojeriza de tal violência que a ideia

\footnotetext{
40 Raaflaub, 2006, loc. 2226.

${ }^{41}$ Forsythe, 2005, pp. 110ss. Forsythe apoia a conjectura de Alföldi, segundo a qual a derrocada da monarquia teria sido causada pela ocupação de Roma pelo rei Porsena, de Clusio.

42 Mazzarino sustenta que no final do período que entendemos como realeza o populus era governado por um magister populi, magistratura que posteriormente foi substituída pelo consulado. (Mazzarino, 2001, pp. 181ss.) Cornell defende a hipótese de que Roma de Sérvio Túlio e Tarquínio, o Soberbo tinha uma monarquia colegiada: o rex sacrorum detinha autoridade cerimonial, e o tirano (ou magister populi) administrava a política; o advento da República foi a derrubada da tirania, e foi permitida a manutenção do cargo sacerdotal de rex sacrorum. (Cornell, 1995, pp. 232ss.)

43 "V'ha invece un valido argomento per ritenere che l'autorità regia sia declinata lentamente presso i Romani; e sta nel fatto che i Re continuarono in Roma ad esistere fino ai tempi più tardi, sia pure con semplice autorità di sacerdoti, ed anche questa, assunta la soprintendenza del culto pubblico del pontificie massimo, più nominale che effettiva." (De Sanctis, 1907, p. 401.) Neste sentido também Arangio-Ruiz, 2006, pp. 27-8.

${ }^{44}$ Raaflaub, 2005a, p. 19; e Momigliano, 1969, p. 395ss.

45 Momigliano, 2005, p. 171.
} 
de uma transição pacífica de fato soa incongruente. Cornell relata inclusive que escavações revelaram sinais de significativa destruição na cidade por volta de 500 a.C. - a Regia, o Comitium e o santuário em Sant'Omobono foram queimados —, o que parece conferir veracidade aos fatos principais da revolução preservada nos anais. Evidentemente, os particulares da narrativa, como o drama de Lucrécia e a eleição de dois cônsules que, por acaso, eram parentes do deposto rei, carecem de credibilidade. ${ }^{46}$

Relevante é a constatação de que as medidas dos dois últimos reis de Roma descritos nos anais têm notável viés anti-aristocrático. Sérvio Túlio reformou a constituição romana, dividindo o povo em novas tribos, instituindo os novos comitia centuriata como principal órgão legislativo e, assim, aumentando a participação política de qualquer romano com os requisitos censitários para lutar no exército ${ }^{47}$. Entre as iniquidades praticadas por Tarquínio, o Soberbo consta o fato de ter decimado o Senado: é clara indicação de severas desavenças entre o monarca e a aristocracia, assim como o é, evidentemente, a posterior revolução que lhe tirou o trono.

De acordo com Raaflaub, a análise da tradição não permite conclusões que não a mais minimalista possível: no final do sexto século, o governo de reis, ou de líderes posteriormente caracterizados como reis ou tiranos, foi substituído pelo governo de famílias aristocráticas, exercido através do Senado e de magistrados de algum tipo, com poder limitado ${ }^{48}$. Após o fim da realeza, o governo passou a ser exercido por dois

\footnotetext{
46 Cornell, 1995, pp. 215ss.

47 Sobre as reformas de Sérvio Túlio, vide Last, 1945. No interessante entender de Momigliano (1969, pp. 594-5), tais reformas foram uma tentativa de parar a crescente separação das ordens na época de Sérvio. Já Bringmann põe em dúvida que os comitia centuriata — os quais, em seu ver, evoluíram a partir um órgão estritamente militar para adquirir importância política — de fato date de tão cedo; segundo ele, ela dataria do fim do quarto ou do início do terceiro século, e teria sido atribuída ao lendário Sérvio Túlio por historiadores séculos depois (Bringmann, 207, pp. 39ss.)

48 Raaflaub, 2005a, p. 30.
} 
magistrados eleitos anualmente, possivelmente cônsules ${ }^{49}$ (ou, em situações emergenciais, por um ditador, com mandatomandato de até seis meses). A aristocracia concentrava inquestionavelmente o poder político, detinha a grande parte das terras (principalmente a exploração do ager publicus), monopolizava o acesso a e o conhecimento do Direito, e exercia o brutal instituto do nexum, a servidão forçada por inadimplemento de dívidas.

Era inevitável a revolta das camadas mais pobres da sociedade, que afinal se deu em 494 a.C.; nascia a plebs qua plebs, que mudaria indelevelmente a organização política de Roma.

49 O cargo de cônsul no início da República, se de fato existia, provavelmente tinha o nome de praetor, que em sua origem remete à liderança militar. Alguns estudiosos crêem que o consulado só se tornou a magistratura de maior poder séculos depois, em 367 a.C. (notadamente ArangioRuiz, 2006, pp. 29ss.); até tal momento, a República teria sido chefiada por um magistrado único, com um colega de menor poder, possivelmente um ditador e seu magister equitum, ou um praetor maximus e um praetor minor (De Martino, 1972, pp. 247ss). 


\section{Capítulo II \\ Os poderes do tribuno da plebe}

\section{A primeira secessio plebis}

Indícios arqueológicos apontam para uma crise econômica catastrófica em Roma no quinto século, corroborada pela raridade da construção de templos nas décadas a partir de 484 a.C., e provavelmente relacionada com os revezes militares sofridos na época, em particular na guerra contra os volscos ${ }^{50}$.

A crise intensificou as necessidades dos menos abastados - em particular, ressentiam-se do cruel tratamento legal de devedores num panorama econômico em que se acumulavam dívidas cada vez maiores ${ }^{51}$ e começaram eles a demandar mudanças.

Em 494 a.C., reza a tradição que a plebs — aqui entendida como os não-patrícios mais necessitados, tanto urbanos quanto rurais: pequenos agricultores, artesãos, comerciantes e outros — se retirou de Roma em protesto, instalando-se no Monte Sacro e se recusando a atender o conclame consular para servir no exército até que suas demandas fossem atendidas.

\footnotetext{
50 Cornell, 1995, pp. 306ss.

51 Como observa Forsythe, é duvidoso que a questão das dívidas tenha sido a grande motriz da secessio, posto que as medidas conciliatórias que apaziguaram a disputa em nada remediaram a existência do nexum; mesmo o ius auxilii tribunício não podia ser utilizado para dele resguardar um devedor. A data da secessio também é suspeita: a resolução da discórdia em 494 a.C. permitiu que os primeiros tribunos e edis plebeus reconhecidos por Roma assumissem seus cargos no exato ano da dedicação do templo de Ceres no Aventino.

Forsythe considera a secessio um mito de criação posteriormente elaborado para o tribunado. Sua hipótese é que essa magistratura foi originalmente criada para complementar o consulado, e que com o tempo havia perdido prestígio junto à aristocracia e adquirido relevância política por seu papel no conflito das ordens (Forsythe, 2005, pp. 170-6).
} 
Há razão para duvidar que a secessio tenha de fato ocorrido: a estratégia de sair da cidade e recusar participação no exército ${ }^{52}$ foi utilizada pela plebe em 287 a.C., o que levaria à lex Hortensia (geralmente considerada o fim formal do conflito das ordens); é possível que a tradição analítica tenha reproduzido retroativamente o ocorrido para explicar a gênese do tribunado e da Assembleia da Plebe. No entanto, o severo tratamento legal conferido a devedores consubstanciado, décadas depois, na Lei das XII Tábuas atesta as dificuldades sofridas pelos mais pobres na época da tradicional primeira secessio; e a criação dos institutos focados na proteção da plebe confirma a incapacidade da elite e a plebe acordarem concessões não paliativas que de fato remediassem os fundamentos da crise social.

Há razoável consenso na doutrina romanista de que, a partir da secessio, ou se originou ou começou a se oficializar um conjunto de instituições políticas que eram exclusivos à plebe: elegeu ela em seu próprio órgão decisório (a Assembleia da Plebe, concilium plebis) oficiais para liderá-la (os tribunos), e dois aediles plebis (que de início serviram como assistentes dos tribunos, e posteriormente teriam como funções precípuas a supervisão da cidade, organização de jogos e gerência dos mercados e do influxo de grãos na cidade, entre outras ${ }^{53}$ ). A eleição dos tribunos e dos edis, doravante, se daria na Assembleia da Plebe.

A plebs fez um juramento solene perante Ceres de proteger seus tribunos: o indivíduo que causasse dano físico a um tribuno seria sacer, maldito. Esta lex sacrata, que seria consubstanciada em lei em 471 a.C., era a fonte última do poder tribunício, pois importava em uma obrigação por

\footnotetext{
52 Raaflaub defende ser implausível que a plebe, no contexto das guerras constantes do início da República que ameaçavam a comunidade por inteiro, tenha utilizado formas extremas de protesto como a recusa do serviço militar (2006, loc. 2421).

53 De Martino crê que a existência dos edis plebeus tenha sido anterior à dos tribunos, e provavelmente datada da organização do culto plebeu (1972, p. 345). Sobre a evolução das funções dos edis, sobre os quais o presente trabalho não se alongará, nota Momigliano (1969, $\mathrm{p}$. 317): "La stessa volontà concorde della plebe, che permise ai tribuni di arrogarsi sempre nuovi diritti, allargò sempre più le funzioni degli edili, affidando loro la sorveglianza della comunità, mentre ai tribuni restava la direzione della attività politica."
} 
parte dos plebeus de defesa da pessoa do tribuno até mesmo com o sacrifício de suas vidas; tal garantia conferiu eficácia política ao instituto do tribunado.

É de fundamental importância para a formação da identidade da plebs que se tenha neste momento demonstrado a força de sua organização religiosa $^{54}$; afinal, em Roma, a religião era indissociável da política (e do Direito), e os patrícios detinham ferrenho controle de seus cargos sacerdotais e dos privilégios a eles associados, notadamente o acesso aos presságios. Entre as concessões que levaram ao retorno da plebs a Roma figurou a promessa da construção, que se realizaria no ano seguinte, de um templo com forte influência grega no Aventino devotado a Ceres, Líber e Libera, deuses da fertilidade de culto essencialmente plebeu. No templo seria estabelecido o acervo histórico e jurídico da plebe, resguardado pelos edis ${ }^{55}$.

No que concerne a relevância das divindades plebeias, observa Wiseman:

"The very fact of a triad of divinities looks like an ideological statement. The grand temple of Jupiter Optimus Maximus on the Capitol, supposedly begun by the first Tarquinius and ready to be dedicated by the second at the time of his expulsion, was a triple cult of Jupiter, Juno and Minerva - the ruler of gods and men, with his wife and daughter. The Aventine triad of Ceres, Liber and Libera sent a very different message, of bread and wine, liberty and law." 56

Segundo a tradição, o senador Menênio Agripa ${ }^{57}$ conseguiu conciliar a plebs e o Senado com o estabelecimento de concessões à plebe:

\footnotetext{
54 Raaflaub, 2005a, p. 23.

55 A partir de 449 a.C., todos os decretos do Senado eram enviados aos edis plebeus para arquivo no templo de Ceres; ao que tudo indica, também eram lá preservados os textos legais aprovados nas demais assembleias. Como aponta Cornell, tal medida sem dúvida constituiu importante concessão à plebe no sentido de garantir maior segurança jurídica contra eventuais alterações arbitrárias por parte do Senado, principalmente considerando-se que as reuniões deste órgão, ao contrário dos comitia, não eram abertas ao público (2005, p. 264).

56 Wiseman, 2004, p. 68.

57 O lendário senador que obteve a paz com a plebs provavelmente deve seu nome à tribo Menênia, uma das tribos com criação atribuída a Sérvio Túlio, que se localizava na área onde fica o Monte Sagrado (Forsythe, 2006, p. 173).
} 
o templo de Ceres, Líber e Libera e a absorção das magistraturas ${ }^{58}$ plebeias (tribunos e edis) na estrutura governamental de Roma; nota-se que o reconhecimento da organização da plebe só seria oficializado em forma de lei em 471 a.C.. Foi erguido um templo a Concórdia para celebrar o acordo.

Cornell entende que não obstante as múltiplas referências na historiografia clássica aos tratados e concessões entre aristocracia e plebs, não restam dúvidas de que na primeira metade do quinto século as organizações plebeias - o "Estado dentro do Estado" - eram órgãos extra-estatais que o Senado se recusou a aceitar. A busca por reconhecimento, para ele, só seria finda em 449 a.C., quando as leges Valeriae-Horatiae confirmaram a legalidade das instituições plebeias após o Decenvirato ${ }^{59}$.

\section{O tribuno da plebe}

O tribunado da plebe, magistratura a que Cícero se refere como "in seditione et ad seditionem nata" ${ }^{60}$ — nascida na sedição e para causar sedição - , foi o mais ímpar marco na evolução do conflito entre plebeus e patrícios. O papel central e controverso do tribuno na política no declínio da República em muito contaminou a tradição analítica em relação aos séculos anteriores ${ }^{61}$. Segundo ela, o tribuno teria emergido da secessio com os poderes que teria até era dos Gracos; tal hipótese é de improvável veracidade. Não é possível, contudo, delinear com qualquer grau de certeza uma evolução gradual dos poderes tribunícios. É seguro supor que o veto

\footnotetext{
58 Nota-se que na presente, por praticidade, ao exemplo de De Martino et al., utilizou-se o termo "magistratura" para se referir ao tribunado, muito embora este não seja tecnicamente uma magistratura, principalmente quando de sua criação. Badian observa que não há na tradição analítica qualquer informação sobre como se deu a gradual assimilação dos tribunado às magistraturas; na República tardia, o tribuno tinha inclusive assistentes: scribae, viatores, accensi (1996, p. 197).

59 Cornell, 1995, p. 260.

60 Cícero, De legibus, III, 19 (2006, p. 248).

61 Forsythe, 2006, p. 171.
} 
tribunício (intercessio), o maior algoz no conflito com o patriciado, não tenha sido concedido à plebs em 494 a.C. ${ }^{62}$, ou pelo menos não com o alcance de sua forma madura da República tardia; já o ius auxilii, instrumento com escopo mais restrito, foi talvez o primeiro poder tribunício, e dele se desenvolveu a mais geral intercessio ${ }^{63}$.

De início, os tribunos eram dois, ou talvez cinco; Lívio menciona as duas possibilidades, aduzindo que em 457 a.C. chegou-se ao número final de dez ${ }^{64}$. Há registro em Diodoro de que foram eleitos quatro tribunos pela primeira vez em 471 a.C.; como seus nomes coincidem com os das quatro tribos urbanas em que o povo romano era dividido, Arangio-Ruiz propõe que na verdade o tribunado se tenha iniciado em nesta data, sendo os magistrados os chefes de cada uma das tribos urbanas, e que sua função inicial tenha sido a de proteger a plebs urbana ${ }^{65}$. Bringmann representa uma corrente diversa sobre a origem do tribunado, elaborada por Mommsen com base nos escritos de Varro: para ele, os tribunos eram a princípio oficiais que comandavam a infantaria romana, e só se ergueram como defensores da plebe na política com o sucesso da elite plebeia em alcançar as mais altas

\footnotetext{
62 Cornell ressalta que se alguma intervenção tribunícia com conteúdo substantivo de intercessio ocorreu no início da República, ela foi entendida como extensão prática da lex sacrata, e não exercício de um poder dos tribunos per se (1995, p. 260).

63 De Martino, 1972, p. 354 "[Chi] rettamente considera il potere giuridico dei tribuni come un potere in continua formazione, il cui fondamento è la forza e la cui giustificazione è la tendenza ad un governo unitario e non di classe, non potrà sorprendersi dei numerosi contrasti, degli insuccessi e delle contraddizioni del movimento plebeo." (p. 357).

64 De Martino, notando que o aumento do número de tribunos para dez é por Lívio citado como uma maior consolidação do poder plebeu e por Diodoro como enfraquecimento do mesmo, conclui que a criação de mais tribunos simplesmente refletiu a crescente participação da plebe na sociedade romana complexidade da organização política da mesma, a qual necessitava, portanto, de mais dirigentes (1972, pp. 349-351).

65 Arangio-Ruiz crê que a lei de 471 a.C. tenha consagrado pela primeira vez os direitos da plebe nela consubstanciados, até então objetos de conflito entre o patriciado e a plebs (2006, p. 46ss.). Cornell ressalta que a exata ordem das palavras utilizadas por Diodoro revela que o que ocorreu em 471 a.C. pela primeira vez foi não a eleição de tribunos, e sim a eleição de quatro deles (1995, p. 449). De Martino lembra que nas tribos eram inscritos tanto patrícios contra plebeus; é inexplicável que plebeus tenham chegado ao posto de chefe das quatro (1972, p. 337).
} 
magistraturas ${ }^{66}$. Em contraste com esta hipótese, Momigliano e Cornell apontam que não ter a Assembleia da Plebe adotado um sistema de votos fundamentalmente militar (ou seja, as centúrias) revela que a plebs que efetuou a secessio era em essência infra classem, ou seja, não participava do exército exceto em emergências ${ }^{67}$. De Martino ressalta que as duas hipóteses anteriores ignoram o fundamento social e econômico do conflito entre as ordens; a plebs não teria como realizar espontaneamente a secessio sem uma organização interna, em que decerto figuravam líderes, escolhidos por seus integrantes, capazes de guiar a ação política em 494 a.C. e, se necessário, uma eventual luta armada ${ }^{68}$.

Qualquer que tenha sido sua origem, o tribunado era uma magistratura colegiada, com indivíduos de equivalentes poderes, com autoridade para intervir nas ações uns dos outros ${ }^{69}$; compartilhavam com as demais magistraturas romanas os princípios da temporalidade, colegialidade, responsabilização findo o mandato e a gratuidade ${ }^{70}$. $\mathrm{O}$ fato de ser o tribunado um cargo não remunerado e o alto custo em que um candidato podia incorrer na campanha eleitoral significavam grande dificuldade na elegibilidade à magistratura para indivíduos não abastados ou que não tivessem um patrono para sua eleição; como aponta Gruen, no declínio da República, período de que sobreviveu o maior número de nomes de tribunos, somente um terço dos tribunos conhecidos não provém de

\footnotetext{
66 "When the leading plebeian families gained access to the highest civil and military office, the tribunate of the plebs emancipated itself from its military roots, namely of a junior command over the infantry, and specialized in its civil functions of protecting the common man in Rome and representing the interests of the plebeian class. Reflecting the rising demands on the tribunate as a result of the growth of the community, it became customary after the epochal year of 366 for the concilium plebis to elect ten tribunes of the plebs instead of the previous six." (Bringmann, 2007, p. 43)

67 Cornell, 1995, p. 261; Momigliano, 2005, p. 175.

68 De Martino, 1972, pp. 338-340.

69 Assim foi, pelo menos, até Tibério Graco demandar à plebs a deposição de seu colega Otávio por ter se oposto a uma proposta de Graco. Vide Konrad, 2006, loc. 2881ss.

70 Grosso, 1965, p. 175.
} 
famílias senatoriais, e muitos destes claramente devem suas eleições a conexões com senadores poderosos como Pompeu e César ${ }^{71}$.

Com o fim da secessio, incumbia aos tribunos a proteção da plebe, como revela o caráter negativo da maioria de seus poderes, os quais thes permitiam interferir em inúmeras situações em que julgassem estarem os interesses da plebs (ou de indivíduos plebeus) em risco. Lívio fala da libertas plebis como "liberdade de", não "liberdade para"; a função do tribuno deveria ser defender, não $\operatorname{atacar}^{72}$.

Eram facultados aos tribunos da plebe - ou ao menos lhes seriam facultados até a República tardia — os seguintes poderes: proteger um plebeu de decisões de outros magistrados (ius auxilii); conclamar e dirigir o concilium plebis no exercício de todas as atribuições legais deste ${ }^{73}$; convocar e discursar em contiones $^{74}$; convocar o Senado ${ }^{75}$; obnuntiatio $^{76}$; e, finalmente, o poder de vetar a ação de qualquer magistrado e do Senado (intercessio).

O tribunado era uma magistratura sem imperium: seu poder, como foi dito, era originalmente derivado do juramento feito pela plebe quando

\footnotetext{
71 Gruen, 1995, pp. 180-9.

72 Vasaly, 1987, p. 222.

73 A Assembleia da Plebe elegia os tribunos e edis, votava plebiscita (os quais, a princípio, só vinculavam a própria plebs), e examinava casos em que tivesse sido clamada provocatio (recurso à plebe contra a decisão arbitrária de um magistrado). Antes da criação dos tribunais criminais permanentes na segunda metade do século II, os tribunos agiam também como promotores perante a Assembleia para processar qualquer magistrado curul por má conduta no exercício de seu mandato (Forsythe, 2006, p. 171).

74 Contiones eram reuniões públicas, convocadas por um magistrado, em que eram discutidas propostas legislativas. A reação do público ali reunido era fundamental para arbitrar o sucesso da medida quando levada às tribos. Se mal recepcionada em contio, a proposta sequer era levada a voto (vide Mouritsen, 2001, loc. 482ss. para uma discussão do público real dos contiones). Era ilegal subtrair a um tribuno a direção de um contio; o pai dos Gracos cometeu tal delito quando censor e foi levado a juízo, sob ameaça de pena de morte (Taylor, 1962, p. 20).

${ }^{75}$ O primeiro caso confirmado em que um tribuno convocou o Senado e presidiu a sessão, que Badian identifica como possível origem costumeira para seu direito de fazê-lo, foi durante a Segunda Guerra Púnica, em que um dos cônsules optou por designar como ditador um amigo na Sicília, criando um precedente problemático, e impediu o debate do assunto no Senado; um tribuno chamou o Senado à discussão, e acabou por ser votada no concilium a nomeação de outro ditador. Na República tardia, em diversas ocasiões tribunos convocaram o Senado ou subtraíram a liderança de uma sessão do magistrado que a presidia (Badian, 1996, pp. 206ss.).

76 Obnuntiatio é o direito de um magistrado observar os céus e pronunciar maus augúrios, caso constatados, efetivamente impedindo a realização de sessão legislativa naquele dia (Bíbulo e três aliados tribunos abusaram deste poder de forma célebre em seu consulado de 59 a.C. com César).
} 
da secessio. No entanto, assim como os magistrados que detinham imperium, os tribunos tinham imunidade de responsabilização civil e penal durante o exercício de seu mandato, e só poderiam ser levados a julgamento após o fim do mesmo. A tribunicia potestas era restrita ao pomerium (isto é, o tribuno não tinha poder fora da $\operatorname{cidade}^{77}$ ); e os tribunos, por sua obrigação de prestar auxilium a quem dele necessitasse, eram proibidos de se ausentarem de Roma por mais de vinte e quatro horas.

Mesmo no segundo século, o tratamento formal conferido o tribuno por parte do Senado ainda era em alguns aspectos, como coloca Badian, digno de "heads of a friendly foreign power": não era permitido ao Senado dar instruções a tribunos, como o era a cônsules; somente podia com eles negociar. Em 100 a.C., tal tratamento já teria se alterado: quando os magistrados foram convocados contra Saturnino por ordem do Senado, os tribunos também o foram ${ }^{78}$.

Só plebeus eram elegíveis à magistratura ${ }^{79}$, que com o tempo passou a integrar-lhes na prática o cursus honorum, a sequência de cargos públicos por que tradicionalmente deveria passar uma carreira política bemsucedida em Roma ${ }^{80}$. Tradicionalmente, o cursus honorum se iniciava, após dez anos de carreira militar, com a questura aos trinta $\operatorname{anos}^{81}$, e a partir do

\footnotetext{
77 Badian nega a autenticidade das duas ocasiões narradas por Lívio em que tribunos foram enviados ao encontro de um generais para lhes impedir de executar determinadas ações, citando a implausibilidade da realização de um segundo sacrum pela plebe para estender a tribunicia potestas para além do pomerium; "the whole point of the tribunes' sacrosanctity was that it could not be tampered with” (1996, pp. 195-6). Sobre a discussão do caso similar em 48 a.C., vide Badian, 1996, 196n.

78 "Tribunician action can only be secured by high-level diplomatic negotiations. It is clear that the tribunes, and the community they represent, are still in some sense outside the Senate and the populus Romanus, and act independently of them. They have to be courteously persuaded" (Badian, 1996, p. 206).

79 Em 59 a.C., um patrício, Públio Clódio Pulcro, famosamente fez-se adotar por um plebeu para ter acesso ao tribunado. Sobre Clódio, vide a seção sobre sacrosanctitas a seguir.

80 Badian, ao examinar o rol de tribunos no segundo século, nota a grande quantidade de nomes de famílias tradicionais plebeias, e aponta que muitos tribunos seguiriam o cursus honorum à pretoria, e por vezes até ao consulado (1996, p. 190). Cornell ressalta, no contexto de sua hipótese descrita a seguir, que a integração do tribunado no cursus honorum foi um elemento essencial para a dissociação do tribuno dos objetivos políticos da plebs menos abastada (1995, pp. 333-344).

81 Patrícios tinham o direito de ser elegíveis para todas as posições do cursus honorum - exceto as magistraturas plebeias, é claro — dois anos antes de seus equivalentes plebeus.
} 
ano seguinte o indivíduo poderia ter acesso a um assento senatorial; mas não havia idade mínima para ser tribuno. Assim, o tribunado foi o passo inicial para a carreira de alguns jovens plebeus ambiciosos com recursos (ou conexões) suficientes para competir pelo disputado cargo e adquirir notoriedade com seu mandato; o tribunado lhes permitia integrar o quórum senatorial mais cedo ${ }^{82}$.

Segundo a tradição, apesar do considerável poder inerente ao tribunado, a maior parte dos tribunos agia de forma relativamente harmônica com os interesses do Senado e da aristocracia ${ }^{83}$. São geralmente identificados dois períodos de atividade tribunícia "de sedição", ou seja, perturbadora do status quo: entre a criação da magistratura e a lex Hortensia de 287 a.C., o dito fim formal do conflito das ordens; e entre o tribunado de Tibério Graco em 133 a.C. e o início do Principado.

Cornell propõe uma data alternativa para o fim do primeiro período mencionado. Se de fato os tribunos nos primeiros e no último séculos da República com frequência não representavam interesses senatoriais e buscavam realizar medidas que favoreciam a plebs, o mesmo não pode ser dito, segundo ele, da maioria de seus sucessores entre 367 a.C. - ano em que, segundo a tradição analítica, foram aprovadas as leges Liciniae-Sextiae e plebeus obtiveram o direito ao consulado - e a época dos Gracos. Como nenhum dos nomes de tribunos da plebe eleitos antes de 367 a.C. constantes nos anais - pode-se inferir, por sua eleição, se tratarem de indivíduos com influência política junto à plebs - figuram entre os nomes de cônsules e tribunos consulares ${ }^{84}$ plebeus nos fasti, Cornell conclui que, antes de 367

\footnotetext{
82 Wiseman (1971, p. 99) cita os exemplos de Célio Rufo e Asínio Pólio, que foram tribunos aos 29 e 27 anos, respectivamente. Sobre a lex Atinia e a evolução do direito de tribunos serem incluídos na lectio senatus censorial, vide Wiseman, 1971, pp. 97ss.

${ }^{83}$ Forsythe, 2006, p. 171.

84 Os tribuni militum consulari potestate (tribunos militares com poder consular) foram uma magistratura que substituiu o consulado em alguns anos entre 444 e 392 a.C.; sobre eles, vide De Martino, 1972, pp. 317ss; De Sanctis, 1907, pp. 7ss.; Grosso, 1965, pp. 104-5; Forsythe, 2006, pp. 234ss; Cornell, 1995, pp. 335ss.. De Martino (1972, pp. 354ss.) discorre sobre a atuação tribunícia na nomeação dos tribunos militares.
} 
a.C., era defeso a indivíduos que tinham ocupado uma magistratura plebeia o pleitear eleição ao consulado. Não havia, assim, identidade entre os magistrados da plebs e senadores plebeus com interesses econômicos alinhados com o patriciado, posto que estes tinham aspirações consulares (muito embora, evidentemente, a elite plebeia tenha feito uso da organização política da plebs em sua busca por acesso às magistraturas).

Se em 367 a.C. de fato retirou-se a proibição e ex-tribunos passaram a ser elegíveis ao consulado - e, com efeito, em 366 a.C. um dos cônsules eleitos é o primeiro exemplo registrado de ex-tribuno chegando à magistratura suprema - alterou-se fundamentalmente a partir desta data a essência do tribunado, que passou então a ser desejável para jovens integrantes da elite senatorial plebeia, e a rotineiramente defender os interesses da nobilitas, a nobreza patrício-plebeia, e não da plebs $^{85}$.

Conforme nota Badian, contudo, Lívio, a principal fonte analítica do período até 167 a.C., é relativamente breve no que concerne o tribunado em sua obra, e menciona poucos tribunos por nome; seu silêncio não é prova de que tribunos em sua maioria serviam a aristocracia, e há referência alhures a leis aprovadas pela Assembleia da Plebe contra os interesses do Senado neste período; há provavelmente outras de que simplesmente não restou registro ${ }^{86}$.

Objeção mais ampla a esta concepção da atividade tribunícia oferece von Ungern-Sternberg, que defende uma interpretação do plebiscitum Atinium (o qual, segundo a doutrina tradicional, garantiu a

\footnotetext{
${ }^{85}$ Cornell, 1995, pp. 333-344. Observa-se que a medida posterior de Sila de proibir a ascensão de tribunos a outros cargos do cursus honorum pode ter sido inspirada por esta tradição.

${ }^{86}$ Badian, 1972, p. 699. "Livy's lack of interest in tribunes and the tribunate is shown by his very haphazard references, not only to their actions, but to their names. (...) The less than fully attentive scholar can be led into a trap: finding no mention of tributes in [T. R. S. Broughton's Magistrates of the Roman Republic] under a given year, perhaps for several years on end, he may conclude that there was no tribunician action; hence further support for the popular view that tribunes must have been the lap dogs of the aristocracy." (1996, p. 189).
} 
tribunos assentos no Senado ${ }^{87}$ ) no sentido de que ele impedia a eleição de senadores ao tribunado. Para von Ungern-Sternberg, tal vedação em pleno segundo século - época em que o conflito das ordens tradicionalmente já teria arrefecido — , interpretada em conjunto com a proibição um indivíduo cujo pai tenha sido magistrado curul de ser tribuno para evitar o exercício de patria potestas contra o magistrado da plebe ${ }^{88}$, é claro indício de que ainda se entendia haver sério conflito de interesses entre o tribuno da plebe e a ordem senatorial, e ser necessária a proteção destes contra a influência daqueles ${ }^{89}$.

Sem dúvida, é por demasiado simplista a generalização acerca das intenções de milhares de tribunos atuantes no decorrer de séculos de vida política; e há diversos registros de ocasiões em que tribunos do período dito “sem sedição" se opuseram, por exemplo, aos recrutamentos ${ }^{90}$. Não obstante a ressalva, é inegável que o declínio da República avultou a figura do tribuno, força motriz de diversas iniciativas populares de grande repercussão; Syme considera que os Gracos iniciaram o que ele denomina a "revolução romana"91.

\footnotetext{
87 Badian relata que o consenso na doutrina é que o plebiscito ordenava censores a incluir no rol de senadores tribunos e ex-tribunos exceto se houvesse razões relevantes para não o fazerem (que deveriam ser anexadas em nota ao censo). O plebiscito não tem data certa; não se sabe a partir de quando tribunos necessariamente passaram a fazer parte do Senado. Badian ressalta que o plebiscito com efeito trocou a independência dos tribunos pela possibilidade de influenciarem decisões políticas como membros do Senado (1996, pp. 202ss.).

88 Vishnia (1996a, pp. 293ss.) tem interpretação diversa da lei citada por von Ungern-Sternberg: segundo ela, a estranha proibição era restrita a patrícios que tivessem se passado por transitio ad plebem, como Caio Servílio Gemino, o edil plebeu e ex-tribuno contra quem ela foi alegada; em caso contrário, as diversas famílias tradicionais plebeias consulares jamais teriam tolerado a permanência de uma lei que tanto lhes limitaria o acesso ao tribunado da plebe durante a vida de um patriarca particularmente longevo. Segundo Vishnia, é provável que a proibição date do início da República, de uma época em que a competição pelas magistraturas patrícias era relativamente mais feroz do que a pelas plebeias, e jovens patrícios talvez eram também atraídos pela possibilidade de poder exercido pelos tribunos da plebe.

89 Vide von Ungern-Sternberg, 2005b, pp. 315ss. para seu questionamento acerca da comumente aceita data de 287 a.C. para o fim do conflito das ordens e sua análise do tribunado de Caio Flamínio.

90 Vide Taylor, 1962, pp. 19ss.

91 "With the Gracchi all consequences of empire - social, economic and political-broke loose in the Roman State, inaugurating a century of revolution. The traditional contests of noble families were complicated, but not abolished, by the strife of parties largely based on economic interest, of classes even, and of military leaders.” (Syme, 2002, p. 16)
} 
O tribunado neste período foi alvo de duras críticas de optimates $^{92}$, as quais atingiram seu cume nas ações de Lúcio Cornélio Sila, ditador que em 80-81 a.C. amordaçou o tribunado sob o pretexto de retorná-lo à dimensão diminuta que tivera quando de sua criação; suas medidas seriam em sua maioria desfeitas na década seguinte, não sem resistência por parte da elite senatorial. O debate sobre poderes tribunícios neste ínterim decerto envolveu o recurso à e a manipulação da tradição analítica para ser utilizada como fonte de legitimidade de determinados poderes e direitos; por mais esta razão é a historiografia sobrevivente de autenticidade dúbia no que concerne o tribunado ${ }^{93}$.

Ainda assim, como frisa Gruen:

"To associate the tribunate with the Gracchi, Saturninus, or Sulpicius Rufus is to forget that ten men held the office every year in Rome, very few of whom are known to have engaged in radical agitation. Veto by a single tribune could cancel any legislation inimical to the ruling class, even if it were sponsored by all nine colleagues. The tribunate was an arm of the aristocracy." 94

Se as seções a seguir são relativamente mais focadas na atuação de tribunos que desafiaram o status quo e propuseram reformas relevantes, tal fato se deve sobretudo às inovações constitucionais por eles provocadas; é provável que uma esmagadora maioria dos tribunos, sobre a qual a tradição nada relata, não exerceu mandatos de grande repercussão na história constitucional romana.

Por fim, como testamento ao enorme poder à disposição do tribuno no sistema político romano, resta apontar que em 23 a.C. Augusto, publicamente abstendo-se das magistraturas mas sem desejar se afastar do controle de Roma, fez-se arrogar pelo Senado (além do maius imperium

\footnotetext{
92 Cícero, por exemplo, frequentemente censura tribunos que, em sua opinião, abusam da magistratura em seus textos (dentre os quais, é claro, figura seu inimigo, o "tribuno patrício" Clódio Pulcro). Vide, entre outras, sua crítica dos Gracos em De legibus III.19-33 (2008b, pp. 157ss.).

93 Forsythe, 2006, p. 233.

94 Gruen, 1995, p. 23. No mesmo sentido, Badian: "The great tribunician families used the tribunate, and the wretchedness of a great part of the Plebs, to achieve power and acceptance. Having achieved it, they clearly lost interest in those grievances, and came to share the basic interests of those whose ranks they had joined." (1996, p. 210).
} 
proconsulare) tribunicia potestas ${ }^{95}$; nos séculos seguintes os poderes tribunícios figurariam entre as atribuições tradicionais e fontes formais de poder do imperador de Roma.

Segue-se uma análise pontual dos três principais aspectos da tribunicia potestas: a sacrosanctitas, a intercessio, e a atuação do tribuno na Assembleia da Plebe.

\section{Sacrosanctitas}

O tribuno da plebe era inviolável. Na secessio, a plebe teria jurado matar qualquer indivíduo que atentasse contra a integridade física de qualquer de seus tribunos; conforme Lívio, tal indivíduo teria suas propriedades confiscadas e doadas ao templo de Ceres no Aventino ${ }^{96}$. A fórmula "sacer esto" (maldito seja) era pronunciada contra o agressor, e o assassinar era um dever sagrado.

Não é possível discernir o nível de agressão que levaria à declaração de um indivíduo como sacer. Segundo Plutarco, Caio Graco em um de seus discursos aludiu à história - provavelmente exagerada - de Caio Vetúrio, um homem condenado à morte simplesmente por não ter dado passagem a um tribuno no Fórum ${ }^{97}$.

Pode-se identificar na sacrosanctitas a base do desenvolvimento consuetudinário dos poderes negativos do tribuno, que, como dito acima, muito provavelmente não surgiram em 494 a.C. em sua posterior forma complexa; se sua intervenção física entre um plebeu e o magistrado que o ameaçava levou à evolução do ius auxilii, seu protesto e, por exemplo, o

\footnotetext{
95 Eder, 1993, pp. 109ss.; Syme, 2002, pp. 336ss.

${ }^{96}$ Lívio, III.55.6-7 (2008, p. 196).

97 Plutarco, Caio Graco, 3.5 (1965, p. 178). Badian duvida que o incidente tenha de fato ocorrido, e o atribui a ficção analítica (1996, pp. 193-5).
} 
bloqueio do acesso de senadores ao Fórum, ou de um magistrado a determinado local decerto levou à intercessio.

Importante derivação prática da sacrosanctitas era o ius auxilii: a intervenção física do tribuno em prol de um plebeu que estivesse sob ameaça de qualquer magistrado, o qual arriscaria atrair sobre si mesmo a punição da lex sacrata caso não se afastasse. No dizer de De Martino, o auxilium era "l'espressione non del diritto ma della forza plebea; esso significa che dietro il cittadino romano che il tribuno prendeva a difendere stava tutta la comunità plebea" 98 .

Os tribunos tinham a obrigação de deixar as portas de suas residências abertas dia e noite para facilitar o acesso de qualquer plebeu em busca de auxilium; também se disponibilizavam em grupo nos bancos tribunícios no Comitium. Cumpre ressaltar, porém, que, em muitos casos de apelo aos tribunos, os mesmos deferiam a decisão ao Senado ${ }^{99}$.

Como extensão do ius auxilii, tribunos tinham coercendi potestas: o poder de fazer valer sua vontade por coerção (multas, aprisionamento ou pena de morte) contra quem se lhes opusesse ${ }^{100}$.

Há uma ocasião de especial interesse, por seu potencial revolucionário, de um exercício extremo do auxilii latio adversus consules contra o arrolamento de soldados. Em 151 a.C., para impedir o recrutamento para a guerra na Espanha, tribunos aprisionaram os cônsules, um ato sem precedentes que ocorreria novamente em em 138 a.C. por motivo análogo ${ }^{101}$. Nota-se que, numa sociedade com guerras tão

\footnotetext{
98 De Martino, 1972, p. 353.

99 A não interferência dos tribunos com o recrutamento de soldados seguia um delicado equilíbrio, entre os interesses do Senado e o apelo individual do cidadão que não desejava ir à guerra; na guerra contra a Macedônia, por exemplo, em resposta ao pedido de auxilium de centuriões, dois tribunos deferiram a decisão aos cônsules, mas os demais declararam que protegeriam qualquer plebeu que fosse aviltado pelo recrutamento (Taylor, 1962, p. 20ss.).

100 Cornell, 1995, p. 259; Grosso, 1965, p. 90.

101 Em 119 a.C., Caio Mário, então tribuno, também ameaçaria o cônsul Metelo Dalmático com prisão, forçando-o a desistir do decreto que estava defendendo; também o tribuno Lúcio Flávio ordenaria em 60 a.C. a prisão do cônsul Metelo Céler, que se lhe opunha insistentemente. David identifica nas duas ocasiões o embate entre a legitimidade do tribuno e dos optimates da elite senatorial que caracterizou a crise do declínio da República (David, 1993, pp. 56-7).
} 
frequentes quanto Roma, ocasionais resistências ao arrolamento foram uma importante arma no arsenal do povo; afinal, seu histórico remonta à secessio e à própria origem do tribunado.

"[Since the secessio,] tribunes are repeatedly represented as obstructing the levy in order to force the patricians to yield to demands for food, for land, for protection against the imperium of the consuls, for the right of intermarriage with patricians, for the opening of the consulship to plebeians. But before 151 the interference never, as far as we know, resulted in the seizure of the consuls by force." 102

A sacrosanctitas foi ignorada de forma lamentável e flagrante em algumas ocasiões na República tardia, notadamente em primeiro lugar no caso de Tibério Graco em 133 a.C. (descrito na seção seguinte, intercessio) e, dez anos depois, de seu irmão Caio.

A partir dos Gracos, o assassinato de um tribuno, para o Senado, passou a ser considerado um mal menor do que permitir a continuada existência de um reformador que tanto apoio popular havia obtido que decerto objetivava se fazer coroar rei de Roma: a mais comum acusação contra agitadores na República ${ }^{103}$.

Ataques contra a sacrosanctitas tribunícia constituíam uma das espécies de crime arcaico de perduellio, comumente traduzido como traição; o assassinato de Saturnino em 100 a.C. levou ao famoso julgamento de Rabírio, um dos responsáveis pela morte do tribuno, por César em 63 a.C., em que o então cônsul Cícero atuou como advogado de defesa ${ }^{104}$.

Aos Gracos se juntariam nas décadas seguintes diversos outros reformadores com propostas hostis aos privilégios senatoriais — alguns deles tribunos, todos assassinados, por vezes em conjunto com dezenas ou centenas de aliados e seguidores inominados — notadamente Lúcio Apuleio

\footnotetext{
102 Taylor, 1962, p. 19.

103 Sobre os precedentes históricos do início da República para o tiranicídio — assassinato de possíveis aspirantes a rei de Roma, decerto utilizados para justificar a morte de Saturnino e dos Gracos - e a manipulação dos mesmos pela tradição analítica pró- e anti-graquiana, vide Lintott, 1970, pp. 12-29.

104 Sobre a interpretação da actio perduellionis como um procedimento ab origine exclusivamente tribunício, vide "Remarques sur la Perduellio" (Magdelain, 1973, pp. 405-422).
} 
Saturnino, Marco Lívio Druso ${ }^{105}$, Públio Sulpício Rufo, Lúcio Sérgio Catilina, Públio Clódio Pulcro e Caio Júlio César.

A historiografia clássica não hesitou em tratá-los como vilões, demagogos, tiranos incipientes, e seus seguidores como uma multidão desordenada, traiçoeira, facilmente manipulada ${ }^{106}$; e nesta mesma linha geral seguiram muitos vultuosos historiadores desde então, incluindo Gibbon, Mommsen e Scullard. Só no século XX começou-se a restaurar a imagem dos populares, resgatando-se o valor de suas intenções reformistas com uma visão equilibrada da violência da hostilidade da oligarquia senatorial estabelecida ${ }^{107}$. Meier se refere a tais reformadores como "outsiders", pela sua habilidade em ver as crises que assolavam a Roma republicana por inteiro, e sua tenacidade em perseguir soluções não paliativas que, apesar de ainda dentro dos limites do sistema constituído, de fato alterariam a fábrica sócio-econômica de seu tempo ${ }^{108}$.

Não se pode dizer que o tribunado perdeu de todo sua proteção sacra, mesmo debilitada, no declínio da República; mas a sacrosanctitas passou sem dúvida a ser sopesada com a ameaça que os tribunicii furores representavam à nobilitas. Após a morte de Tibério Graco, os libri Sibyllini ordenaram aos cônsules que apaziguassem a deusa Ceres pela morte de seu tribuno. Foram enviadas pelo Senado oferendas ao templo da deusa na Sicília, numa tentativa de expiação ${ }^{109}$. Tal tentativa claramente não representava real constrição; quando Caio Graco chegou ao tribunado, com um programa reformista mais amplo e sofisticado que seu irmão — no dizer

\footnotetext{
105 É extremamente questionável a caracterização de Druso como popularis, apesar do caráter reformador de seu tribunado, principalmente na questão dos povos itálicos, e da resistência que encontrou, culminando com seu assassinato; como diz Lintott: ele "might be popularis in method, but optimate in aim" (1971, p. 448). Seu objetivo era sem dúvida auxiliar a nobilitas a reconquistar o apoio da plebe, dos equites e dos povos itálicos (Badian, 1962, p. 223).

106 Sobre o tratamento dos populares em Lívio, vide Seager, 1977, pp. 377-390.

107 Para uma crítica mordaz do tratamento dado aos populares na historiografia tradicional, vide Parenti, 2004, pp. 13ss.

108 Meier, 1996, pp. 35ss.

109 Wiseman, 2004, p. 192. Vide também Spaeth, 1990, pp. 182-195 para uma interpretação desta oferenda como legitimação da morte de Tibério como tiranicídio.
} 
de Mommsen, as leis de Caio eram "nothing else than an entirely new constitution"110 —, acabou por ter o mesmo fim de Tibério.

Ainda que a elite senatorial tenha deixado de respeitar a sacrosanctitas do tribuno, o povo romano não deixou de conferir-lhes apoio e proteção. Todos os grandes reformadores da República tardia tinham o vocal apoio de seus seguidores, que diversas vezes foram massacrados pelo grupo armado que, a mando dos optimates, objetivava silenciar o tribuno com aspirações por demais audazes. Assim foi com Tibério, Caio e Saturnino. Cícero, em suas múltiplas invectivas sobre o assunto, lamenta que seu grande inimigo Públio Clódio Pulcro tenha uma temível turba a seu serviço aterrorizando as ruas de Roma. Quando Clódio, então já ex-tribuno, foi assassinado enquanto viajava numa emboscada por um grupo de trezentas pessoas liderado por Tito Ânio Milão (outro ex-tribuno, também renomado pelos seguidores armados à sua disposição; sua defesa pelo homicídio de Clódio foi efetuada por Cícero) o povo de Roma reagiu à notícia de sua morte com tamanha revolta que invadiu o Fórum e fez uma pira funérea para Clódio com os bancos do Senado ${ }^{111}$.

Poucos anos depois, Caio Júlio César, ao violar os limites constitucionais de seu imperium com a marcha sobre Roma, utilizou como pretexto não só sua dignitas vitimada pela não autorização do Senado de sua candidatura a cônsul como também o violento ataque ao então tribuno Marco Antônio, que com seu colega Cássio tentara vetar a medida do Senado que declarava César inimigo de Roma se não cedesse comando de seu exército. $\mathrm{O}$ veto foi ignorado; o Senado votou um senatus consultum ultimum. Antônio e Cássio se viram obrigados a fugir da cidade disfarçados, e César, em seu discurso para a décima terceira legião,

\footnotetext{
110 Mommsen, 1894c, p. 344.

111 Para uma perspectiva mais equilibrada da turbulenta carreira de Clódio do que a retratada na historiografia tradicional, que tende a se alinhar com Cícero no assunto, vide: "Cicero and Clodius: The Question of Credibility" (Rundell, 1979, pp. 301-328) e "The Patrician Tribune" (Tatum, 1999).
} 
conclamou seus soldados a vingar a ofensa a seu comandante e ao tribunado da plebe ${ }^{112}$.

\section{Intercessio}

A intercessio, ou veto tribunício, é, no dizer de Grosso, o centro e a característica fundamental dos poderes dos tribunos, inclusive quando, superado o conflito das ordens, usaram-na para defender interesses gerais do povo romano ${ }^{113}$. De Martino se refere à intercessio como "la forza della plebe in azione"114. Não se pode precisar em que momento histórico o instituto da intercessio se constituiu como tal (Badian refuta veementemente uma instância reportada por Dionísio de veto contra votos nos comitia em 483 a.C. ${ }^{115}$ ); mas reza a tradição que os tribunos adquiriram a prática de ficar à porta do Senado para interpor seu veto quando necessário.

Todos os magistrados romanos tinham o direito de vetar as ações de seus pares; só o poder de veto do tribuno se estendia também às ações de qualquer magistrado ou do Senado. Somente os atos do ditador não podiam ser objeto de intercessio; foi esta uma das razões para Sila e César, ao buscarem promover grandes reformas constitucionais, se fizeram nomear ditadores ao invés de se aterem ao consulado.

A intercessio tinha ainda outros limites. Por ser extensão da sacrosanctitas, ela requeria a presença física do tribuno antes, durante ou imediatamente após a execução do ato vetado; sendo assim, era inútil contra o imperium militar de qualquer comandante - que necessariamente deixava de exercê-lo ao adentrar o pomerium, sendo óbvias exceções a esta

\footnotetext{
112 Syme, 2002, p. 48; Gruen, 1995, pp. 490ss.; César, De bellum civile, I.7.

113 Grosso, 1965, p. 89.

114 De Martino, 1972, p. 358.

115 Badian, 1996, p. 192.
} 
regra as invasões de Sila e a de César com seus respectivos exércitos - e tinha circunscrita sua aplicação à cidade de Roma.

O conteúdo do veto também tinha limites ideológicos costumeiros: sua finalidade constitucional era impedir ou fazer cessar ações de magistrados ou do Senado que fossem contrárias ao interesse da plebe. Como exemplo disto, temos o caso de quatro tribunos que, ao se levantarem contra uma lei de 188 a.C., foram persuadidos a não a vetarem para que as tribos decidissem por si próprias sobre o conteúdo proposto. Tal limite foi questionado na República tardia, como será visto abaixo.

O tribuno Caio Cornélio foi levado a julgamento pelo crime de maiestas - dano à soberania do povo de Roma - por, em 67 a.C., ter ignorado o veto de outro tribuno e lido o conteúdo de uma lei sobre corrupção eleitoral num contio. Cícero, ao defender o tribuno, frisou que ele havia lido a lei a título de informação para reexame futuro, e, obedecendo a intercessio, havia cancelado o contio após terminar. A motivação política do julgamento era clara; Cornélio havia sido questor sob Pompeu, e as testemunhas da acusação eram antagonistas de Pompeu. O próprio tribuno que havia vetado o contio testemunhou a favor de Cornélio, e ele acabou por ser absolvido ${ }^{116}$. Em 62 a.C., caso similar ocorreu com o tribuno Cecílio Metelo. Ele foi impedido de ler sua rogatio pelo tribuno Catão Uticense, que lhe arrancou o texto; Cecílio então passou a recitá-lo de memória, levando outro tribuno a lhe encobriu a boca com as mãos ${ }^{117}$.

Tamanha era a força da intercessio que geralmente sua mera ameaça por vezes já bastava para extinguir uma lei incipiente, como demonstra a atuação do tribuno Druso contra a lei de Caio Graco estendendo cidadania romana. Observa Morstein-Marx que a utilização da intercessio (ou a ameaça dela) contra uma lei ao ser ela proposta perante a plebe retira desta o poder soberano de apreciar leis na Assembleia; é uma

\footnotetext{
116 Gruen, 1995, pp. 263-5.

117 David, 1993, pp. 53-4.
} 
intervenção de qualidade duvidosa, por partir de um magistrado que - em tese - existe para servir a plebe.

Ditava o costume, baseado nas regras não escritas de concordia que orientava toda a vida política romana, que o veto a uma lei não deveria ser interposto antes de que ela fosse discutida em contio; presumivelmente, entendia-se que a intercessio não deveria obstar a que o povo formasse sua própria opinião acerca da questão em tela ${ }^{118}$. Nota Badian que, diferindo tribunos acerca de determinada matéria, o veto era utilizado - se sequer o era - para atrasar a apreciação da medida nos comitia e permitir a devida consideração do assunto ${ }^{119}$.

Morstein-Marx ressalta que muitas iniciativas legislativas tinham sua popularidade observada nos contiones $^{120}$, e, na ausência de apoio popular, sequer chegavam a ser proposta para votação e possível veto na Assembleia da Plebe; sustenta ele que o poder do veto legislativo se exercia sobretudo na ameaça de seu uso para sublinhar a expressão da vontade popular no debate in contionibus. Havendo apoio popular à lei, a intercessio não deveria ser usada pelos demais tribunos para impedir que o povo a aprovasse, e de fato não o foi com sucesso, mesmo no turbulento declínio da República:

"The pattern is very clear in the cases on which we are best informed: the tribunician veto could not stop Ti. Gracchus' land law, the lex Gabinia de piratis, and Julius Caesar's agrarian bill, nor, of course, Clodius' legislative onslaught in 58, despite the presence of anti-Clodian tribunes that year." 121

\footnotetext{
118 Morstein-Marx, 2004, pp. 124-5.

119 Badian, 1972, p. 699.

120 Morstein-Marx reconhece que a audiência em contiones tendia a ser favorável a quem o convocasse, que provavelmente reunia aliados, clientes, indivíduos subornados ou contratados para influenciar quem mais estivesse presente a reagir a favor da proposta e vaiar oponentes da mesma que porventura se manifestassem; não obstante, ele ressalta a frequente referência aos contiones na historiografia do declínio da República como prova de sua importância no cotidiano político romano (2004, pp. 130ss). Vide também Mouritsen, 2001, loc. 482ss.

121 Morstein-Marx, 2004, pp. 124ss. Badian corrobora a afirmativa de que não há registro de veto impedindo a Assembleia de votar, ressalvando-se alguns poucos casos de privilegium contra o qual um tribuno concedeu auxilium ao indivíduo em questão (1972, p. 699).
} 
Para melhor discussão de como o tribunado de Tibério Graco ${ }^{122}$ afetou o mos no que concerne a intercessio, cumpre um breve exame da votação de sua lex agraria. Temendo rejeição, Tibério a apresentou diretamente ao concilium plebis, ao invés de - como era mais comum levar a proposta primeiramente ao Senado. Tal atitude, embora não sem precedentes e de acordo com o $\operatorname{mos}^{123}$, foi posteriormente interpretada como um sinal de hostilidade.

A lei agrária de Tibério encontrou na Assembleia da Plebe enorme apoio popular. Porém, ela teve seu voto pelas tribos vetado por outro tribuno, Marco Otávio, agindo em prol dos interesses da maioria do Senado, cuja posse de ager publicus seria ameaçada pela lei. Foi a primeira instância de um veto tribunício sendo usado explicitamente contra os evidentes interesses do povo ${ }^{124}$.

Após uma tentativa infrutífera de mediação por parte do Senado, Tibério tentou novamente introduzir sua lex agraria, e mais uma vez Otávio a vetou; também tal repetição do veto, com a clara finalidade de impedir que a plebe apreciasse determinada medida, não tinha precedentes ${ }^{125}$. Nas palavras de Konrad: "Octavius was departing from mos, and in so doing, raised a political dispute to the level of a constitutional crisis." 126

A irregularidade do veto de Otávio, interposto precisamente antes do início da votação, foi — no contexto do veto de Trebélio contra Aulo Gabínio em 67 a.C., em circunstâncias idênticas — objeto de crítica

\footnotetext{
122 Sobre o confronto das diversas fontes na discussão dos motivos de Tibério para a realização de sua reforma, vide Badian, 1972, pp. 675ss.

${ }^{123}$ Konrad, 2006, loc. 2872.

124 Segundo Forsythe, 2006, p. 171, relatos esparsos de patrícios utilizando plebeus para impedir propostas reformistas podem seguramente ser atribuídos à interpolação da tradição analítica posterior. Vide também Badian, 1972, pp. 668ss., arrolando diversas ocasiões anteriores em que a elite senatorial não buscou (ou não encontrou) utilizar um tribuno para vetar uma lei perante a plebs em prol da nobilitas.

125 Cornell, 1995, p. 270.

126 Konrad, 2006, loc. 2872.
} 
inclusive de Cícero, segundo quem o desejo de um tribuno não deveria prevalecer sobre as vozes de todo o povo ${ }^{127}$.

A solução de Tibério para resolver o impasse foi outro rompimento com a tradição estabelecida: ele propôs à plebe que votasse para demover Otávio do cargo de tribuno, pelo abuso da intercessio. A medida obteve sucesso, e Tibério assim atingiu o âmago do princípio do colegiado, fundamental para o Direito Público Romano: era essencial para a manutenção do sistema político que os poderes dos indivíduos exercendo a mesma magistratura fossem equiparáveis, e cada um encontrava na atividade do outro o limite para o exercício de seu próprio poder.

A lex agraria foi por fim aprovada; mas quando Tibério, ameaçado com a possibilidade de ser responsabilizado em juízo por seus inimigos pelos atos de seu mandato, decidiu buscar sua imediata reeleição para o tribunado, acabou por ser fim assassinado, junto com muitos de seus seguidores, por um grupo liderado por Cipião Nasica, pontifex maximus, agindo em prol da maioria de optimates no Senado; pela primeira vez, discórdias políticas entre um tribuno e o Senado escalavam até levar à morte de um magistrado que, em tese, seria inviolável.

Há registro de diversas ocasiões na República tardia em que representantes dos optimates se elegeram tribunos e utilizaram seu poder de veto para deter medidas favoráveis aos comandos de indivíduos como Mário, Pompeu e César (que agiam, na opinião dos tribunos em questão, contra os interesses da res publica). Não é preciso olhar além da eleição ao tribunado de Marco Pórcio Catão Uticense, senador estóico considerado extremamente conservador até pelos optimates, para verificar que a tribunicia potestas à época servia às duas correntes opostas; se os populares haviam alargado o poder do tribunado com os Gracos, os optimates não deixaram de utilizá-lo como recurso contra inovações indesejadas.

127 Cícero, Pro Cornelio I, frag. 31. 
Da mesma forma, é claro, Mário, Pompeu e César também tinham tribunos a seu serviço para promover legislação de acordo com seus objetivos e vetar iniciativas e ações que lhes tolhiam poderes. Não é exagero dizer que, na República tardia, adquirir um tribuno da plebe ou fazer eleger um aliado ao tribunado era essencial e inestimável para a carreira de um general de porte, principalmente considerando a mercurial disposição do Senado em relação a comandantes de grande vulto.

O colégio dos tribunos virou, afinal, arena de debate entre partidários de um general ou outro, ou seus opositores. A intercessio era a principal defesa destes tribunos contra iniciativas adversárias; sua maior arma, contudo, era a propositura de medidas no concilium plebis.

\section{Atuação na Assembleia da Plebe}

O concilium plebis (Assembleia da Plebe) era uma assembleia aberta a todos os não patrícios. Inicialmente, os votos no concilium teriam sido contados com um sistema de cúrias, como os antigos comitia curiata; Cornell sustenta que tal presunção é resultado da natural familiaridade dos analistas com as formas romanas de voto por categorias; e que a alternativa óbvia para um observador externo é que ab initio as reuniões da plebe tenham sido organizadas de forma grega, com contagem de votos diretos e maioria simples ${ }^{128}$. A partir de 471 a.C., a Assembleia passou a ter suas votações organizadas com o sistema de tribos, o qual garantia uma relativamente mais igualitária - mas, para os padrões modernos, ainda extremamente desvantajosa - contagem dos votos dos presentes, em contraste com cúrias ou centúrias ${ }^{129}$, e limitava a influência de possíveis

\footnotetext{
128 Cornell, 1995, p. 261.

129 Para Cornell, a utilização do sistema de tribos revela a intenção de assegurar que a plebe rural encontrasse no concilium representação equivalente à plebe urbana, que por evidentes razões práticas tinha mais facilidade em comparecer a sessões da Assembleia (1995, p. 261).
} 
clientes que, a mando de seus patronos, comparecessem às votações para agir contra os interesses da plebs ${ }^{130}$.

Quando de sua criação, o concilium plebis votara plebiscita: legislação que só vinculava a plebe. Diz a tradição que uma das três leges Valeriae-Horatiae de 449 a.C. conferiu eficácia para com todo o povo às leis votadas pela Assembleia da Plebe; em 339 a.C., a lex Publilia estabeleceu o mesmo; e por fim a lex Hortensia, em 287 a.C., reiteraria o escopo dos plebiscita.

Para De Martino, é impensável que a plebs de 449 a.C. pudesse ter a força política necessária para que suas resoluções vinculassem todo o povo romano; não se pode considerar a lex Valeria-Horatia histórica ${ }^{131}$. Em sentido contrário à doutrina que entende somente a lex Hortensia como real, aponta Cornell que há registro de diversos plebiscita antes de 287 a.C. que indubitavelmente tiveram força de lei, alguns deles de grande relevância para a história da plebs, como as leges Liciniae-Sextiae (367 a.C.) e a lex Ogulnia (300 a.C.). A solução oferecida por Cornell é que a lex ValeriaHoratia conferiu ao concilium plebis o poder de legislar para todo o povo romano, mas restringiu sua capacidade para fazê-lo unilateralmente, por exemplo, exigindo de tais leis prévia auctoritas patrum ou um voto por todas as tribos nos comitia tributa. A lei de 339 a.C. pode ter removido em parte tais restrições, e a lex Hortensia as retirou por completo ${ }^{132}$. Badian concorda com tal suposição, apontando que a concessão da lex ValeriaHoratia provavelmente se deu devido à necessidade de autoridades em Roma com poder de propor legislação, já que os cônsules se ausentavam da cidade com frequência para comandar exércitos ${ }^{133}$.

\footnotetext{
130 De Martino, 1972, pp. 346-8.

131 De Martino, 1972, pp. 373-7.

132 Cornell, 1995, pp. 277-8. Sobre a análise da peculiaridade da dita "lex" Icilia de Aventino publicando, vide Cornell, 1995, pp. 261ss.

133 Badian, 1996, pp. 211ss.
} 
A exigência de auctoritas patrum — aprovação formal de uma lei, provavelmente com fundamento religioso - foi reduzida a mera formalidade por uma das leges Publiliae de 339 a.C., que estabeleceu que ela deveria ser conferida antes do voto de uma lei, e não depois. Cornell infere que a auctoritas patrum funcionava na prática para o Senado como um poder de veto a posteriori das deliberações da Assembleia da Plebe, atestando que a lei era tecnicamente aceitável e não continha falhas religiosas; a lex Publilia dificultou que o patriciado declarasse uma deliberação da plebs inválida com base em um detalhe procedimental ${ }^{134}$.

Quaisquer que fossem as exigências das duas leis anteriores, tenham existido ou não, há consenso na doutrina romanista: com a lex Hortensia de 287 a.C. as deliberações da plebe sem dúvida passaram a vincular de pleno direito todo o populus ${ }^{135}$.

Relata Lívio que em 287 a.C. a plebs se revoltou contra o opressivo endividamento em massa que sofria e mais uma vez efetuou uma secessio. Tribunos haviam tentado criar leis regulamentando a questão das dívidas, mas as leis não tiveram efeito por obstrução da elite. Badian observa que nesta época a concessão de auctoritas patrum a legislação plebeia já era suficientemente comum que sua não concessão no caso foi o choque que levou à crise ${ }^{136}$. Segundo von Ungern-Sternberg, a paz com a plebs revolta foi atingida com a indicação do ditador Quinto Hortênsio - provavelmente um líder respeitado entre os plebeus, pois não era de nenhuma família tradicional distinta em Roma - e a promessa da lex que levaria seu

\footnotetext{
134 Cornell, 1995, p. 341.

135 Sobre a relação entre auctoritas patrum e auspicia, e a possibilidade de tribunos terem desenvolvido uma forma própria de auspicia para o concilium plebis, principalmente após a lex Hortensia, vide Badian, 1996, pp. 197ss.

${ }^{136}$ Badian, 1996, p. 212.
} 
nome ${ }^{137}$. Como aponta Raaflaub, ainda que a lex Hortensia seja considerada o fim do conflito entre as duas ordens por significar a assimilação completa da organização plebeia no sistema político romano, pode-se vislumbrar em sua matéria a manutenção das tensões sociais que continuariam vigentes em Roma, entre a nobilitas patrício-plebeia e as camadas da população menos favorecidas política e economicamente ${ }^{138}$.

A partir deste ano, portanto, o populus romano passou a votar suas leis pelo sistema de tribos tanto no concilium plebis, restrito a plebeus (também denominado comitia tributa plebis), quanto nos comitia tributa, que incluíam patrícios. Desde Mommsen, observou-se na doutrina romanista excessiva cautela na distinção entre estas duas assembleias. Tal ortodoxia é muito questionada atualmente, posto que não se trata de uma distinção observada sequer na historiografia romana com exatidão; como aponta Lintott, após a lex Hortensia, a principal diferença prática entre as duas era se o magistrado que convocava as sessões era um magistrado curul - caso em que se tratava tecnicamente de uma reunião dos comitia tributa — ou um tribuno da plebe — caso em que era o concilium plebis. Sequer se sabe com segurança se patrícios eram admitidos nas sessões do concilium plebis que deliberavam sobre assuntos que também lhes diziam respeito; mas certamente não lhes era permitido participar das votações ${ }^{139}$.

A lex Hortensia foi um marco na dita transição do tribunado de defensores da plebs a apoio da nobilitas, problematizada nas seções anteriores. No dizer de Grosso, "le funzioni positive che esercitavano nei riguardi della comunità plebea diventarono funzioni pubbliche nello

\footnotetext{
137 Segundo von Ungern-Sternberg, a visão da lex Hortensia como o termo do conflito das ordens é errônea: "The lex Hortensia was only practicable if the range of issues subject to plebiscite was relatively restricted and the extent of the demands fairly easy to anticipate - in other words, if they were not expected to threaten the system. In addition, the very fact that the plebeian part of the nobility could be represented among the ten tribunes (and was therefore capable of controlling the college by means of intercessio) would have helped to make such an agreement possible. (...) the antagonism between the orders was not abolished by the lex Hortensia, but actually institutionalized." (2005b, pp. 319ss.)

138 Raaflaub, 2005b, p. 185.

139 Lintott, 1999, pp. 50ss..
} 
Stato"140. De fato, não se pode constatar relevante conexão substantiva entre muitas das leis levadas ao concilium plebis e o interesse direto da plebs; o tribuno - com evidentes exceções — se tornou na prática somente mais uma forma de se exercer atividade legislativa na ordem constitucional romana.

A gama de assuntos sobre que as assembleias romanas deliberavam era ampla, e incluía qualquer alteração constitucional, mudança em cargos religiosos oficiais, concessão de cidadania romana, fundação de colônias, divisão de ager publicus, distribuição de grãos a preços reduzidos à plebs urbana, inovação em Direito privado (embora a partir do segundo século legislação processual tenha sido sobretudo elaborada por pretores) e em Direito penal, sobretudo a criação de novos tribunais, permanentes ou não. Tradicionalmente, entende-se que ficava a cargo do Senado a ratificação de tratados a partir de 171 a.C., bem como a declaração de guerra e deliberações sobre política externa ${ }^{141}$.

Cidadãos privados em tese poderiam se manifestar nos comitia antes da votação de uma lei, mas na prática somente membros da elite senatorial o faziam. Não era possível a propositura de qualquer emenda ou mudança nas medidas apresentadas nas assembleias; só se votava pela sua aprovação ou não. Curiosamente, há muito poucos registros de propostas de leis negadas pelo povo. Ao contrário de supor que tal fato significa ser a votação mera formalidade, Morstein-Marx frisa a importância dos contiones na formação e predição da opinião do povo sobre o assunto votado $^{142}$. Como relata Tácito, às vésperas do voto de legislação controversa, havia contiones diários, com magistrados praticamente dormindo na Rostra, onde faziam discursos ${ }^{143}$. Mouritsen aponta a

\footnotetext{
140 Grosso, 1965, p. 85.

141 Lintott, 1999, pp. 200ss..

142 Morstein-Marx, 2004, p. 124.

143 Tácito, Diálogo sobre a oratória, 36 (1942, p. 764).
} 
frequência com que projetos de lei mal recebidos nos contiones eram retirados por completo, ou alterados e então apresentados para votação ${ }^{144}$.

Faz-se necessária uma breve nota sobre o voto nas assembleias romanas. Era um problema comum - embora constituísse crime, com punições severas - a intimidação, por vezes violenta, ou supervisão por parte dos mais poderosos de indivíduos no momento do voto de legislação controversa $^{145}$. A substituição do voto oral pelo secreto - pela lex Gabinia de 139 a.C. nas eleições, pela lex Cassia de 137 a.C. nas assembleias judiciais, e pela lex Papiria de 131 a.C. nas assembleias legislativas - decerto teve grande impacto na até então comum prática de nobres fiscalizando votos de outrem; o voto livre era particularmente relevante nas pouco povoadas primeiras classes das comitia centuriata, em que cada voto poderia fazer uma enorme diferença ${ }^{146}$. Quando tribuno em 119 a.C., Caio Mário introduziu uma lei que tornou mais estreita a passagem para a urna de votação: assim, só um indivíduo por vez poderia chegar até ela, e era impossível que outros inspecionassem o conteúdo de seu voto.

Ao longo dos séculos, diversos tribunos se destacaram por apresentar reformas de grande alcance perante a Assembleia da Plebe. O próximo capítulo relatará as principais inovações que levaram à maior paridade entre patrícios e plebeus; foge ao escopo da presente, por óbvia constrição espacial, um histórico de todas as leis de iniciativa tribunícia.

Ainda assim, cumpre ressaltar que mereceu especial atenção de diversos tribunos durante toda a República a questão agrária: os limites para a utilização de ager publicus, o estabelecimento de lotes em novas colônias e a concessão de terras para veteranos. De um lado, havia na nobilitas (e,

\footnotetext{
144 Mouritsen, 2001, loc. 835.

145 Estranhamente, não há registro de o suborno de eleitores (ambitus), um problema recorrente na eleição de magistrados na República, ter ocorrido no voto de leis nos comitia. Para um histórico do suborno e de seu tratamento legal em Roma, vide "Electoral Bribery in the Roman Republic" (Lintott, 1990, pp. 1-16).

146 Taylor, 1962, p. 26. Vide também "Secret Ballot and Its Effects in the Late Roman Republic" (Yakobson, 1995, pp. 426-442).
} 
posteriormente, também entre os equites ${ }^{147}$ ) um significativo grupo de grandes detentores de terras, que resistiam a quaisquer tentativas de lhas limitar a posse. De outro, na plebs urbana sempre havia contingente buscando se estabelecer no campo; e veteranos de guerra passaram a ver como direito adquirido a concessão de lotes após seu serviço a Roma nas legiões. A constante tensão entre os dois grupos levou à produção de - e a violentas resistências a - diversas leges agrariae de magnitude e escopo variados durante os séculos ${ }^{148}$. Destacam-se na história da regulamentação da posse agrária em Roma, entre outras, as leis dos tribunos Caio Flamínio, Tibério e Caio Graco e do cônsul Caio Júlio César.

Devido aos requisitos censitários para a participação no exército, a concessão de terras tinha a fundamental consequência de aumentar o número efetivo de soldados disponíveis; por exemplo, o franco declínio da natalidade e da produção das fazendas verificado nos censos a partir de 164 a.C. refletiu-se na dificuldade de convocar soldados em 151 a.C., mencionada supra. Por esta razão, como nota Taylor, é frequentemente perceptível a coincidência de anos em que houve discussão de alguma reforma agrária e o recrutamento de soldados para guerras; e, como foi dito, durante toda a República tribunos se ocuparam de legislar e intervir em ambos os assuntos ${ }^{149}$.

Resta apontar uma faceta peculiar da atividade tribunícia: a responsabilização de magistrados e generais perante a plebe após o decurso

\footnotetext{
147 Os equites, ou membros da ordem equestre, assim chamados por preencherem os requisitos censitários para possuir um cavalo fornecido por Roma, eram em essência a elite econômica nãosenatorial; eles foram atores políticos de grande importância no fim da República. Em cerca de 130 a.C., uma lei da Assembleia da Plebe forçou senadores a abrirem mão de seus cavalos públicos, forçosamente os excluindo das dezoito centúrias dos equites (Mommsen, 1894c, p. 300). Criou-se assim uma clara separação entre os dois grupos, que se confrontariam com frequência a partir da lei judiciária de Caio Graco, que determinou a inclusão de equites nos júris, até então reduto exclusivo da elite senatorial. Para uma análise do papel de Caio Graco na formação da identidade da ordo equester, vide Rowland, 1964, pp. 361ss.

148 Para uma análise das leges agrariae e dos mais comuns erros da historiografia ao delas tratar, vide Ridley, 2000, pp. 459ss.

149 "Tribunes were particularly interested in conditions for the levy, and, with traditions going back through Gaius Flaminius and Licinius and Sextius to the Early Republic, they regarded the distribution of land under agrarian laws as their special function.” (Taylor, 1962, p. 24)
} 
de seu mandato. A partir do terceiro século, em que há registros de tais casos (de vericidade mais aceitável do que o clássico caso de perduellio de Hortênsio), acusações por crimes contra o povo eram apresentadas por tribunos, edis e questores ao concilium plebis; casos em que poderia ser aplicada a pena de morte eram reservados aos tribunos. Mesmo nos casos de alguns julgamentos com pena capital efetuados fora da cidade de Roma por um magistrado há registro da intervenção de tribunos, interpretada por Lintott como garantia dos direitos do acusado, ainda que este não tenha feito uso da provocatio $^{150}$.

A vergonhosa impunidade de Sérvio Sulpício Galba em 149 a.C. que foi alvo de investigação tribunícia por sua atuação contra os lusitanos e conseguiu evitar a condenação com um emotivo apelo ao povo em prol de seus filhos - levou à criação pelo tribuno Lúcio Calpúrnio Piso de um tribunal permanente, presidido por um pretor e com um júri senatorial, para processar magistrados acusados de extorquir povos aliados e subjugados a Roma: a quaestio de repetundis ${ }^{151}$.

A quaestio de Piso foi possivelmente o primeiro tribunal permanente de Roma (até então, quaestiones eram criados ad hoc, em geral para lidar com questões ou problemas específicos). Outras se seguiram nas próximas décadas, entre as quais a quaestio de maiestate de Saturnino e as quaestiones de Sila, que em sua reforma constitucional preservou todas as quaestiones até então existentes. Caio Graco em seu tribunado de 123 a.C. havia mudado a composição do corpo de jurados - que tradicionalmente era composto de senadores - dando a ele acesso aos equites (alguns entendem que Caio substituiu por inteiro a composição de senadores por equites; de qualquer forma, foi uma importante conquista para os plebeus mais abastados que não faziam parte do Senado); Sila restaurou o

\footnotetext{
150 Lintott, 1999, pp. 149ss.

151 Taylor nota que, embora a historiografia frequentemente atribua o crédito pela criação deste tribunal ao Senado, as traiçoeiras ações deste no próprio ano de 149 contra cartaginenses revela o caráter de Piso na elaboração da lei (Taylor, 1962, pp. 24-5).
} 
monopólio dos senadores no júri, muito embora tenha também determinado o aumento no número de senadores para 600 , presumivelmente recrutando centenas de equites.

Como observa Lintott, a partir da criação das quaestiones o populus perdeu o controle da punição de magistrados irresponsáveis, que passou a ser controlado pelo Senado. Apesar de tráfico de influência e suborno serem lingua franca no convencimento do júri, cerca de metade dos casos levados às quaestiones perpetuae de que há registro resultaram em condenações, enquanto antes de sua criação não há registro algum de condenação à pena capital em julgamentos perante a Assembleia ${ }^{152}$.

Por fim, resta mencionar a provocatio - o recurso à plebe -, uma garantia constitucional contra qualquer julgamento ou pena. $\mathrm{O}$ acusado condenado por qualquer outro magistrado tinha o direito de apelar ao tribuno, que agia como promotor no caso perante a plebe; as tribos votavam então seu veredicto. A provocatio era um dos mais importantes limites à arbitrariedade dos magistrados em Roma.

A data de origem da provocatio é controversa: a tradição analítica reporta três leges Valeriae, datando de 509, 449 e 300 a.C., garantindo o direito à provocatio. Para grande parte da doutrina romanista, inclusive Raaflaub, só a terceira lei é real; ele atribui a criação das demais à posterior presunção por parte dos analistas de que uma garantia de tamanha importância decerto haveria existido desde a fundação da República ${ }^{153}$. Cornell, no entanto, aceita a veracidade das três leis, apontando que o texto da Lei das XII Tábuas presume a existência da provocatio; que o propósito da segunda foi garantir, após o decenvirato, a não criação de magistraturas imunes à provocatio; e que, por não haver registro do conteúdo da lei de 300 a.C., não é possível discernir seu exato objeto ${ }^{154}$.

\footnotetext{
152 Lintott, 1999, p. 201ss.

153 Raaflaub, 2005b, p. 187.

154 Cornell, 2005, pp. 276-7. Neste sentido também Develin, 2005, p. 326.
} 
Em 294 a.C. houve o primeiro caso confirmado de provocatio por um patrício, que Badian aponta como um notável exemplo do fato de que o conflito das ordens já era sem dúvida então findo ${ }^{155}$.

$\mathrm{Na}$ República tardia, o tribuno Clódio criou uma lei confirmando o direito à provocatio em termos até então inéditos: a lex previa a sanção de morte ao indivíduo que condenasse alguém à pena capital sem julgamento. Foi uma clara reação às execuções a mando de Cícero sob o senatus consultum ultimum por conta da conspiração de Catilina; mas, para desagrado dos optimates, por ser uma lei meramente zelando por uma das mais basilares e tradicionais liberdades do povo romano, não era possível obstar sua promulgação ${ }^{156}$.

155 Badian, 1996, p. 212.

156 Tatum, 1999, pp. 153-4. Sobre provocatio, vide também Develin, 1978, pp. 45-60; Staveley, 1955, pp. 412-428. 


\section{Capítulo III \\ O tribuno e a estabilidade da República}

\section{A Lei das XII Tábuas}

Após as concessões da secessio, a próxima grande conquista da plebe no início da República foi a elaboração da Lei das XII Tábuas, às quais Lívio hiperbolicamente se refere como a fonte de todo o Direito público e privado ${ }^{157}$; ela seria a única obra legislativa de seu escopo em Roma até as Institutas justinianas. Esta lei foi um marco na ascensão dos plebeus por lhes conferir um grau de segurança jurídica até então impensável em Roma; mas, ao mesmo tempo, ela revela com obviedade a opressão da plebe que assolaria a sociedade romana pelos séculos séculos a seguir. A contradição inerente ao tratamento da Lei das XII Tábuas como conquista na plebe se traduz com clareza no tratamento dado pela tradição analítica do episódio de sua criação ${ }^{158}$.

As demandas da plebe por codificação se iniciaram em 462 a.C., no tribunado de Caio Terentílio Harsa, e continuaram no decênio que se seguiu. Como narra Lívio, foi enviada em 454 a.C. uma comissão à Grécia para estudar legislações como a elaborada por Sólon, e com inspiração nesta criar o primeiro código escrito compreensivo do Direito Romano; tal viagem é no geral desacreditada na doutrina moderna ${ }^{159}$. Ainda assim, as similaridades e diferenças entre as circunstâncias que levaram à codificação

\footnotetext{
157 Lívio, III.34 (2008, p. 174).

158 Vassaly, 1987, p. 213.

159 Como aponta Cornell, se romanos tivessem visitado a Atenas de 454 a.C., Péricles lhe teria oferecido como guia legislação mais atualizada do que as leis de Sólon; embora se possa discernir influência grega nos fragmentos da Lei das XII Tábuas, é mais provável que ela tenha partido das cidades gregas do sul da Itália (Cornell, 1995, p. 275). De Martino nota que se tal viagem ao sul da Itália ocorreu, pode ter se tratado de uma medida dilatória por parte da facção senatorial que se opunha à realização da lei (De Martino, 1972, p. 304).
} 
em Atenas e Roma podem engendrar conclusões de peculiar interesse, como será relatado abaixo.

Lívio menciona que houve conflito entre a plebs e a elite sobre a inclusão de plebeus no decenvirato, o grupo de dez magistrados escolhidos em 451 a.C. para elaborar a lei no decurso de um ano; a plebs acabou por aceder ao monopólio do patriciado na comissão, sob a condição de que sua ocupação de ager publicus no Aventino (o plebiscito chamado lex Icilia de Aventino publicando) e outras leges sacratae fossem mantidas ${ }^{160}$. Todas as magistraturas - incluindo os tribunos da plebe - foram suspensas durante o mandato dos decênviros, de cujas decisões não poderia haver recurso algum.

Após o decurso de um ano, havia dez tábuas prontas, de notável qualidade; elas foram aprovadas pelos comitia centuriata. Houve consenso de que se faziam necessárias mais duas. Foram eleitos decênviros, muitos deles plebeus ${ }^{161}$, para continuar a tarefa no ano seguinte. Contudo, Ápio Cláudio, que também havia feito parte do primeiro decenvirato, revelou-se um homem iníquo, e, como escreve Lívio, moldou o caráter de seus colegas e, em segredo, começaram a planejar tomar o poder para além de sua comissão transitória, criando um decenvirato vitalício. $\mathrm{O}$ segundo decenvirato foi especialmente cruel no pronunciamento de sentenças abusivas contra plebeus; e tal crueldade se demonstrou notadamente na inclusão da proibição de casamento entre patrícios e plebeus na décimaprimeira tábua.

Decorrido o ano, não propuseram eleições, confirmando as suspeitas do povo de que desejavam se ver reis (“dez Tarquínios”, no dizer de Lívio ${ }^{162}$ ); derrotas para sabinos e équos desmoralizaram ainda mais os decênviros. Por fim, a cobiça de Ápio Cláudio por uma mulher plebeia,

\footnotetext{
160 Lívio, III.32 (2008, p. 173). Vide também Cornell, 1995, pp. 261ss..

161 Lívio relata o nome de todos os decênviros, sem mencionar seu status; romanistas identificam seis dentre os dez com nomes de gentes plebeias.

162 Lívio, III.39 (2008, p. 180).
} 
noiva de um ex-tribuno, levou a um corrupto julgamento em que ela foi por Cláudio considerada escrava de um seu associado, e a jovem foi assassinada por seu próprio pai a fim de poupá-la da desonra nas mãos do decênviro.

Embora Lívio atribua parte da culpa pela iniquidade do segundo decenvirato à plebe - que, com seu ódio pelo consulado como instrumento da elite, insistiu, a despeito da oposição do Senado, na criação da comissão extraordinária; que, em sua cega ambição por maior libertas, abriu mão de suas garantias por excelência (o tribunado e a provocatio) e permitiu aos decênviros o acúmulo de autoridade que lhes afinal corromperia; que foi facilmente seduzida pelas vazias promessas do vil Ápio Cláudio e o elegeu duas vezes ao cargo - ele nota que os emotivos apelos do pai da jovem sensibilizaram a plebe já descontente e, sob a liderança do ex-tribuno Icílio, esta realizou uma segunda secessio, e não voltou a Roma até obter garantia da eleição de tribunos e da deposição dos decênviros.

A narrativa de Lívio revela o conflito das ordens num estágio feroz: a plebe tolerou que suas garantias fossem tolhidas para evitar a eleição de cônsules; o Senado, embora também odiasse os decênviros, tolerou seu governo pela conveniência de não haver mais tribunos, e porque suas medidas abusivas afetavam sobretudo a plebe. Os senadores - que até então haviam se retirado para suas moradas campestres, se afastando da política citadina - só colaboraram com o fim do decenvirato quando o exército em massa se juntou à plebe urbana em secessio.

Decerto não se pode aceitar a dramática obra de Lívio como histórica sem análise pausada de seu conteúdo. Logo se nota no evento a inclusão, como na narrativa sobre Tarquínio, o Soberbo, de uma casta jovem sob assalto como catalisador da revolta: era ela plebeia, é claro, para sublinhar a vilania da proibição de casamento entre as ordens; o assalto à sua virtude por Ápio Cláudio é um paralelo à ameaça à libertas dos 
cidadãos romanos pela tirania do decênviro ${ }^{163}$. O relato dos decênviros tem evidentes similaridades com a história dos trinta tiranos de Atenas ${ }^{164}$. Quanto às ações de Cláudio, fazem-se necessárias ressalvas quanto à sabida antipatia de Lívio pela gens Claudia ${ }^{165}$, ao conflito entre populares e optimates retroagindo para colorir suas alegadas ações insidiosas, e possivelmente à influência das medidas de Sila e do segundo Triunvirato na caracterização do exercício do poder pelo segundo decenvirato ${ }^{166}$.

A constituição deste segundo decenvirato de maioria plebeia é de historicidade duvidosa ${ }^{167}$. Embora reporte seus nomes, Lívio não faz menção a uma conquista de tamanha relevância. Além disso, é peculiar que precisamente o decenvirato que incluiu plebeus tenha sido mais cruel em suas provisões que o anterior: não se pode sequer arguir que os propósitos da elite plebeia estavam em descompasso com a plebs, pois a proibição de casamento entre patrícios e plebeus atingia mais diretamente aquela do que esta. Segundo von Ungern-Sternberg:

"[The] second Decemvirate owes its fictitious existence precisely to the ban on intermarriage, the only law that explicitly mentions patricians and plebeians and at the same time segregates them. This flagrantly contrasts with the principle of equality before the law, which the Twelve Tables established for all citizens in every other respect. Later observers, it seems, simply could not believe that the great lawgivers of Rome were capable of such a contradiction." 168 .

Cornell discorda da visão de von-Ungern-Sternberg, ressaltando a contradição da fabricação analítica incluir plebeus no decenvirato inventado para lhes justificar a afronta; também aponta que a tradição é unânime ao atribuir ao consulado que se seguiu à secessio — dos benéficos Valério e Horácio, que garantiram a restauração das instituições plebeias em suas

\footnotetext{
163 Vasaly, 1987, p. 221.

164 Forsythe, 2005, pp. 223-4.

165 Sobre o tratamento de Lívio do decênviro e dos demais Ápios Cláudios em seus cinco primeiros livros, vide Vasaly, 1987, pp. 203-226.

166 Vide "The Formation of the "Annalistic Tradition": The Example of the Decemvirate" para uma análise mais detalhada da construção da narrativa do segundo decenvirato (von UngernSternberg, 2005a, pp. 75ss.). Contra: Cornell, 1995, pp. 274ss.

167 Nota-se que, entre outros, Momigliano (2005, p. 180) sustenta ser o segundo decenvirato autêntico.

168 Von Ungern-Sternberg, 2005a, p. 79.
} 
leges - a ratificação das últimas duas tábuas, que incluíam a polêmica proibição.

Também questiona Cornell o propósito do decenvirato, apontando que em nada a formação de um grupo transitório de legisladores para a elaboração de leis importa a suspensão de todas as magistraturas, e teoriza que, sendo o decenvirato uma nova magistratura anual com o propósito de assumir as funções de todas as outras magistraturas e integrar a plebs no Estado, deveria ser aberto a indivíduos de ambas as ordens; não há por que se colocar em dúvida, segundo ele, a existência do segundo decenvirato ${ }^{169}$. Eder frisa que se pode inferir a partir da necessidade de restauração do tribunado da plebe pela lex Valeria-Horatia de 449 a.C. a intenção de se abolir a magistratura ${ }^{170}$.

Neste sentido também De Martino desenvolve a teoria de que o decenvirato foi um parêntese de breve vitória da plebs, aliada a uma facção do Senado, provavelmente liderada por Ápio Cláudio, que também via vantagens na criação do decenvirato. Este, ainda segundo De Martino, foi assim uma magistratura aberta a patrícios e plebeus, e sua constituição foi uma tentativa de encerrar o monopólio patrício do comando de Roma; por esta razão, foi consagrado na narrativa analítica como um hostil ensaio de regnum.

De Martino segue Diodoro ao atribuir a elaboração das últimas duas tábuas da lei a Valério e Horácio de 449 a.C., após a queda dos decênviros. As leges propostas por estes cimentaram o fracasso da tentativa de maior paridade no acesso ao poder, restaurando a alteridade da organização plebeia e o anterior monopólio das magistraturas pela elite ${ }^{171}$.

Qualquer que tenha sido a composição do decenvirato, cumpre a análise das consequências da lei que dele emergiu. A Lei das XII Tábuas,

\footnotetext{
169 Cornell, 1995, p. 273ss..

170 Eder, 2005, p. 258.

171 De Martino, 1972, pp. 297ss.
} 
embora trate de seus constituintes com patente dureza, estabeleceu maior igualdade entre a plebs e a elite perante a lei, e faz distinção entre adsidui e proletarii em poucas das cláusulas que sobreviveram até a atualidade. De Martino frisa ainda como vitórias a inclusão na Lei das XII Tábuas e nas subsequentes leges Valeriae-Horatiae o impedimento da constituição de magistraturas que não fossem subjugadas à provocatio $^{172} \mathrm{e}$ a restauração do tribunado, com plenos poderes ${ }^{173}$. É inegável a relevância da possibilidade de conhecimento do Direito por parte dos cidadãos; não ser ele mais dependente de revelação pelos colegiados religiosos patrícios ou patrimônio exclusivo dos juízes restringia a arbitrariedade judicial e, com efeito, em última análise beneficiava todo o povo romano. Cumpre ressaltar, porém, que o Direito processual romano permaneceu extremamente complexo e formulaico, de difícil acesso ao povo; e as fórmulas de procedimento legal, as legis actiones, foram publicadas somente 150 anos depois da Lei das XII Tábuas ${ }^{174}$.

A organização plebeia tinha compreensível apreço pela ideia de lei escrita; como aponta Cornell, esta foi uma invenção grega adotada pela plebs em relação tanto aos seus próprios plebiscita quanto aos decretos senatoriais e leis aprovadas nos comitia, todos os quais eram arquivados no templo de Ceres ${ }^{175}$.

Eder oferece uma perspectiva diversa sobre o propósito da Lei das XII Tábuas: que elas tenham sido criadas, não por demanda da plebe, mas sim por iniciativa da aristocracia confrontado com turbulências sociais, com a finalidade primária de estabilizar o status quo para melhor sustentar sua predominância, reforçando códigos de conduta social uniforme,

\footnotetext{
172 Para Eder, contudo, a positivação do apelo ao comitiatus maximus (provavelmente os comitia centuriata), a permissão para este executar punições com pena capital e a fixação de pena específica para devedores na Lei das XII Tábuas tinha como fim minar a utilidade do ius auxilii tribunício, que não podia ser utilizado para intervenção contra pena prevista em lei escrita (Eder, 2005, p. 258).

173 De Martino, 1972, pp. 310-1.

174 Eder, 2005, p. 259.

175 Cornell, 1995, p. 264.
} 
restringindo a formação desregrada de regras costumeiras por julgamentos imprevisíveis e fortalecendo direitos patrimoniais, essenciais para a prosperidade da oligarquia. A pretensa neutralidade do Direito positivado, ficção que afasta a realidade da classe dominante como criadora do Direito, faz dele o instrumento ideal para legitimar e mesmo aumentar o poder da elite que, na jovem República, buscava se estabelecer como tal.

Utilizando como base de comparação o desenvolvimento da legislação grega, Eder ressalta que tanto em Atenas quanto em Roma há um marcado descompasso entre a alegada demanda das classes desfavorecidas pela codificação e seu ganho real consubstanciado na lei resultante. Considerando-se, como indicam as fontes, o nexum e a pobreza em grande escala os dois maiores problemas sócio-econômicos que assolavam a República de 450 a.C., é revelador que eles tenham sido mantidos no texto da Lei das XII Tábuas. Se de fato houve inspiração no exemplo grego, foi esta: a compreensão de que um direito material bem estabelecido conferia estabilidade à ordem política e social pré-existente, e ajudava na homogeneização dos interesses da classe dominante.

Em Roma, como em Atenas, estava em perigo o monopólio do poder político por parte da aristocracia, cuja perda poderia levar à perda de poder econômico; mas em Roma, ao contrário de Atenas, o perigo à ordem estabelecida era intrínseco: a ascendência da plebs na figura revolucionária do tribuno, e não a ameaça de tirania. Conclui Eder:

"The main goal was to reintegrate the plebs into an order of community and
state that was exclusively defined by the patricians themselves. For it was not
the plebs that wanted to build up a state within the state, but the patricians who
excluded it by insisting on forming the state according to their own ideals. To
secure the homogeneity of the patricians and the economic status quo were only
secondary goals. Nevertheless, those secondary goals were pursued
effectively." 176 Resta um breve comentário sobre a mais controversa provisão da Lei das XII Tábuas: a restrição do ius conubii, impedindo o casamento entre patres e plebeus. Segundo Lívio, a proibição causou ódio na plebs, e foi 
revogada cinco anos depois pela dita lex Canuleia $^{177}$, criada por um tribuno da plebe. Nota-se que, para a doutrina majoritária, é peculiar a ocorrência de um plebiscito eficaz perante patrícios quase dois séculos antes da lex Hortensia de 287 a.C.; aponta-se como solução possível a questionável existência da lex Valeria-Horatia de 449 a.C. permitindo tal eficácia mas provavelmente impondo-lhe substanciais restrições ${ }^{178}$.

Forsythe rejeita a validade da proibição do ius conubii por completo, atribuindo a tradição a respeito a um erro de interpretação do texto da Lei das XII Tábuas; para ele, historiadores nos séculos seguintes à criação desta entenderam uma restrição que originalmente vedava o casamento de sacerdotes (patres) com plebeus, exigindo que todos os patres se casassem com o rito de confarreatio, como aplicável a todo o patriciado $^{179}$.

O confarreatio, um rito arcaico de casamento, aparentemente restrito a patrícios, era exigido dos flâmines e do rex sacrorum mesmo séculos depois; por sua evidente antiguidade, ele foi entendido por Mommsen como a forma original de casamento em Roma ${ }^{180}$. Já Linderski interpreta o histórico da instituição de forma diversa: as características mais antigas e privadas da cerimônia seriam resquícios do confarreatio original, sem restrição de classe; a posteriori, foi adicionado ao rito um elemento público - a participação do flamen Dialis e do rex sacrorum - que necessariamente limitaram sua utilização a um número reduzido de aristocratas, tornando o confarreatio em uma instituição estatal e uma forma notável de diferenciação do patriciado da plebe.

A tentativa de separação das ordens no âmbito da cerimônia de casamento, para Linderski, teria culminado na referida proibição dos

\footnotetext{
177 A rogatio Canuleia foi, segundo Lívio, permitida em 445 a.C. como concessão à plebe para silenciar mais contundentes demandas pelo acesso de plebeus ao consulado.

178 Cornell, 1995, pp. 277ss..

179 Forsythe, 2005, p. 229.

180 Mommsen, 1894a, pp. 72ss.
} 
decênviros, objetivando principalmente impedir que mulheres patrícias se casassem cum mano (sujeição legal) com plebeus, e estabelecer um mito da necessidade de "pureza de sangue" para a integridade dos auspícios e preservação dos cargos sacerdotais em Roma ${ }^{181}$.

Cornell interpreta o dispositivo como restrição ao casamento com membros da organização plebeia, com o objetivo de dissuadir membros da elite plebeia de se envolverem nesta ${ }^{182}$. Eder interpreta a restrição ao ius conubii como não só um revés para plebeus na elite como também uma tentativa de inviabilizar a continuidade das famílias patrícias cuja subsistência econômica e política dependia de alianças com famílias plebeias $^{183}$.

\section{A nobilitas}

Nas décadas após a lex Canuleia revogar a proibição de casamento entre patrícios e plebeus, a paridade das ordens perante a lei avançou consideravelmente. Entre 444 e 392 a.C., os cônsules foram por vezes substituídos no comando de Roma por "tribunos consulares" (tribuni militum consulare potestate), alternando-se os tipos de magistratura suprema de tempos em tempos; como concessão à plebe pela manutenção do monopólio patrício do consulado, alguns destes tribunos eram plebeus ${ }^{184}$. Nota-se que patrícios dominaram o rol de cônsules e tribunos consulares entre 444 e 401 a.C. (com as possíveis exceções de dois tribunos, em 444 e 422 a.C.); após esta data, há alguns registros de tribunos plebeus ${ }^{185}$.

\footnotetext{
181 Linderski, 2005, pp. 223ss..

182 Cornell, 1995, pp. 291-2.

183 Eder, 2005, p. 258.

184 A tradição analítica atribui a constituição dos tribunos consulares a necessidades militares, mas tal afirmação não se sustenta com base nos registros dos fasti e dos próprios analistas. Para uma discussão do panorama político que provavelmente levou à escolha no período por um ou outro tipo de magistratura, vide De Martino, 1972, pp. 317ss; Cornell, 1995, pp. 335ss..

185 Cornell, 1995, p. 336.
} 
Em 367 a.C., uma das leges Liciniae-Sextiae — de iniciativa de dois tribunos da plebe, Caio Licínio Estolão e Lúcio Sexto Laterano permitiu o acesso de plebeus ao consulado; as outras duas objetivaram, respectivamente, aliviar o endividamento e limitar a quantidade de ager publicus que um indivíduo poderia ocupar.

As interpretações do significado original da lex variam. Para Cornell, que sustenta ter havido cônsules plebeus desde a fundação da República, a restrição revogada foi na realidade o impedimento a plebeus stricto sensu - isto é, participantes da organização política da plebs, extribunos e edis da plebe - de ascenderem ao consulado ${ }^{186}$. Arangio-Ruiz, por sua vez, sustenta que a lex Licinia-Sextia foi a real instituição do consulado em Roma ${ }^{187}$.

Segundo Lívio, a lex estipulava que um cônsul tinha que ser plebeu, e a lex Genucia de 342 a.C. permitia que ambos o fossem (algo que não ocorreria até 173 a.C.). Como a partir de 342 a.C. os fasti começam a listar regularmente um cônsul plebeu e um patrício, a doutrina romanista majoritária concluiu que a lex Genucia estabeleceu a obrigatoriedade de um cônsul plebeu a cada ano, e a lex Licinia-Sextia de 367, a possibilidade ${ }^{188}$.

A lex Licinia-Sextia consolidou a formação da elite romana patrício-plebeia: consideravam-se nobiles os descendentes de consulares (ex-cônsules), sem grande distinção de status entre patrícios e plebeus ${ }^{189}$; no dizer de Badian, membros da elite plebeia vieram a ser considerados na prática "patrícios honorários", não obstante a reserva de certos parâmetros religiosos ${ }^{190}$. A maior diferença era, $\mathrm{o}$ acesso às magistraturas da plebe para

\footnotetext{
186 Cornell, 1995, pp. 334ss..

187 Arangio-Ruiz, 2006, p. 29.

188 Oakley, 2004, p. 30. Cornell oferece a hipótese de que, em 173 a.C., houve controvérsia sobre se a eleição de dois cônsules plebeus estava de acordo com o estabelecido na lex Genucia; como esta se referia somente à obrigatoriedade de um plebeu no consulado e não garantia o mesmo a um patrício, entendeu-se que não havia violação à lei. A tradição analítica erroneamente supôs, por causa deste debate, que este era o propósito original da lex (2005, p. 338).

189 Forsythe, 2005, p. 160.

190 Badian, 1996, p. 210.
} 
estes, e para aqueles a faculdade de galgarem os cargos do cursus honorum dois anos mais novos do que seus equivalentes plebeus, e o instituto do interrex. É relevante, contudo, a reserva de tantos cargos para patrícios quando estes eram sem dúvida numericamente inferiores à crescente elite plebeia; ainda havia um certo privilégio inerente a fazer parte do patriciado, mesmo na República tardia.

À conquista do consulado seguiram-se rapidamente a ditadura (356 a.C.), a censura (351 a.C.), a pretoria (336 a.C.). Diversos cargos sacerdotais (pontífices e áugures) tiveram seu número aumentado pela lex Ogulnia em 300 a.C. para acomodar o acesso de plebeus; após a eleição de plebeus ao posto de rex sacrorum (255 a.C.) e pontifex maximus (254 a.C.), somente os arcaicos flaminatos maiores (flamen dialis, martialis, quirinalis) permaneceram restritos a patrícios.

Jovens plebeus de várias famílias de renome, como os Cláudios Marcelos, os Aurélios Cotas e os Fúlvios, tradicionalmente eram eleitos ao tribunado antes de proceder às demais magistraturas. Um mandato relevante como tribuno da plebe era importante para a familiarização do eleitorado com o indivíduo ${ }^{191}$. O tribunado tinha posição algo fluida no cursus honorum plebeu, pois não fazia parte dele oficialmente; por exemplo: um ex-cônsul, Marco Fúlvio Flaco, foi tribuno em 122; e um ex-pretor, Lúcio Volcácio Tulo, foi possivelmente tribuno em 68 a.C. para obter notoriedade suficiente para se candidatar ao consulado no ano seguinte ${ }^{192}$.

É comumente aceito que com o acesso plebeu às magistraturas e o reconhecimento progressivo das instituições plebeias, culminando com a lex Hortensia em 287 a.C. e o estabelecimento da validade dos plebiscita para todo o povo romano, findou o conflito das ordens como tal; os conflitos sociais em Roma passariam então a ser compreendidos como ricos versus pobres. $\mathrm{O}$ acesso ao Senado e às magistraturas curuis era restrito aos

\footnotetext{
191 Gruen, 1995, p. 24.

192 Syme, 1963, p. 59.
} 
nobiles, com eventuais ascensões de equites ou de um ou outro raro homo novus que se destacara no tribunado ${ }^{193}$ ou no exército (ou, no caso de Cícero, na advocacia). Quanto às camadas mais pobres da plebe, é evidente que a abertura do consulado a nobres plebeus em nada lhes aliviou a situação ${ }^{194}$, mas houve também inovações a elas benéficas neste período: diversas medidas legislativas nas décadas seguintes procuraram remediar a perpétua crise de endividamento e, em 326 ou 313 a.C., o nexum foi formalmente abolido; os sucessos militares de Roma garantiam um fluxo constante de nova mão-de-obra escrava, e as conquistas levavam à criação de novas colônias e distribuição de terras ${ }^{195}$.

Para von Ungern-Sternberg, podem-se perceber momentos de afirmação da identidade independente da plebs como tal mesmo após esta data, principalmente na ação de tribunos como Caio Flamínio e seus seguidores; por isso, ele desenvolve a hipótese de se considerar como fim do conflito das ordens a época da Segunda Guerra Púnica ${ }^{196}$. A fragorosa derrota sofrida para Aníbal em Canas em 216 a.C. ajudou a unificar os interesses da plebe e do Senado no sentido de recuperar o poderio romano; os tribunos inclusive cederam ao desejo dos cônsules e levaram ao concilium uma impopular proposta de lei sobre o arrolamento de jovens com menos de dezessete anos nas legiões ${ }^{197}$.

Badian identifica na integração do tribunado às magistraturas representada pela admissão regular de tribunos e ex-tribunos ao Senado no segundo século - a mudança fundamental na função do tribuno na res publica: ele se afastou de sua função precipuamente defensiva, de controle algo externo externa ao embate político da elite, para integrar a práxis

\footnotetext{
193 Sobre um estudo do novi homines no tribunado, vide Wiseman, 1971, pp. 158ss.

194 Badian, 1996, p. 210.

195 Raaflaub, 2006, loc. 2402.

196 Von Ungern-Sternberg, 2005b, pp. 312ss.

197 Taylor, 1962, pp. 20-1.
} 
constitucional regular como propositor frequente de legislação em prol do órgão de que agora fazia parte ${ }^{198}$.

Não por acaso, o período seguinte à Segunda Guerra Púnica foi caracterizado na historiografia clássica como a época áurea da concordia na política romana, o auge das instituições em sua melhor forma ${ }^{199}$; algumas décadas depois, porém, o tribunado de Tibério Graco sinalaria o início da "Revolução Romana"200.

\section{A emergência dos populares}

A designação de popularis foi atribuída na doutrina romanista em retrospecto a diversos nobiles dos últimos séculos da República que em determinados momentos de suas carreiras agiram em prol das camadas mais necessitadas da plebe, como Cipião Africano. Mesmo a caracterização de clássicos populares da República tardia como tais é questionada, pois é impossível discernir na tradição analítica se sua real motivação ao advogar medidas favoráveis à plebe era sobretudo seu próprio avanço político, provocar caos institucional, ou, no caso de Tibério e César, vindicar sua dignitas ferida.

Quaisquer que tenham sido as motivações dos expoentes entre os populares da República tardia, tem maior relevância o estudo de suas ações, e suas consequências. Os Gracos e os demais populares revelaram problemas sérios existentes na sociedade romana - principalmente no concernente às camadas mais pobres da plebe, e aos povos itálicos - e propuseram soluções, as quais muitas vezes não foram executadas por interferência do Senado.

\footnotetext{
198 Badian, 1996, p. 211.

199 Develin, 2005, p. 293.

200 Syme, 2002, pp. 16ss.
} 
Cumpre ressaltar que jamais houve em Roma um "partido" ou "movimento" popularis que não as costumeiras alianças transitórias entre os senadores, seja por afinidade política, seja por troca de influências ou vantagens econômicas; os populares agiam por excelência sozinhos, com apoio eventual de certas facções entre os senadores e o suporte popular que lhes deu o nome. Não se pode subestimar o papel do carisma pessoal dos principais populares em sua busca por consenso entre o povo ${ }^{201}$. Ademais, frisa-se que alguns populares decerto optaram por seguir esta linha política devido à resistência senatorial que enfrentaram por quaisquer outras razões; só lhes restava cortejar o apoio da plebe para garantir sua própria sobrevivência política.

De acordo com Mouritsen, o grande diferencial da atividade dos populares foi o encorajamento que suas atividades e métodos representaram para que indivíduos das camadas mais baixas da população comparecessem às assembleias e contiones, até então geralmente dominada por plebeus de algumas posses, posto que estes tinham o tempo livre disponível para comparecer a eventos políticos ${ }^{202}$. Embora, como foi dito acima, haja registro de atividade tribunícia em oposição aos interesses do Senado desde a primeira secessio, os populares se destacaram por conclamarem à ação as até então quase politicamente invisíveis parcelas mais pobres da plebs urbana.

Para ganhar apoio a suas medidas, Tibério Graco inclusive realizou campanha junto à plebs campestre, buscando reunir votos suficientes nas trinta e uma tribos rurais, com que a elite até então presumivelmente exercera grande influência. Como não há registro de demais populares fazendo uso deste recurso, é provável que os ruidosos debates de suas medidas tenham sucedido em obter o suporte de um contingente de votantes tamanho que incluísse também cidadãos inscritos em tribos rurais pelo

\footnotetext{
201 David, 1993, pp. 50-1.
}

202 Vide Mouritsen, 2001, loc. 251ss. 
domicílio de seus antepassados e que porventura residissem em Roma. A organização da plebs urbana para efeitos políticos evoluiu com os sucessivos tribunos populares, destacando-se neste sentido Clódio e suas infames gangues. A proposta de Tibério sobre reeleição e a reeleição de Caio falharam por inconstante apoio popular; já no século seguinte não há um registro sequer de legislação popularis em que tenha fraquejado o suporte do povo ${ }^{203}$.

O assassinato de Tibério rompeu com a práxis de concordia até então estabelecida entre até mesmo os tribunos mais agitadores e o Senado, formando o precedente para os futuros pretensos "tiranicídios" de Caio, Saturnino e outros (precedente este citado inclusive por Cícero como plenamente justificado para excusar o assassinato de Clódio ${ }^{204}$ ).

Como sublinha Goldsworth, o que levou à morte dos populares mais radicais não foi simplesmente a oposição ferrenha às suas reformas, mas também o medo do poder e influência que estes populares estavam adquirindo com suas ações. A elite optava por protelar a solução de algumas crises para evitar que um só indivíduo obtivesse o crédito e, com isso, a gratidão e suporte inabalável de milhares de cidadãos ${ }^{205}$.

Os optimates utilizavam métodos variados para tentar conter tribunicii furores: isto é, o furor tribunício de atuação legiferanda com potencial visto como nocivo pela elite senatorial. $\mathrm{O}$ uso da intercessio por tribunos aliados aos optimates já foi discutido no capítulo anterior. Cumpre mencionar também a obstrução religiosa ${ }^{206}$ por meio de obnuntiatio, o direito de sacerdotes e áugures investigarem os céus em busca de portentos que inviabilizariam a realização de assembleias legislativas no dia em

\footnotetext{
203 Mouritsen, 2001, loc. 1047ss.

204 Cícero, Pro Milone, III.7 (2008a, p. 197).

205 Goldsworth, 2007, pp. 49-50.

206 Badian teoriza acerca da existência de auspicia próprios à Assembleia da Plebe e questiona a possibilidade de áugures terem autoridade de impedir legislação plebeia em 1996, pp. 200ss..
} 
questão. Segundo a doutrina, as leges Aecia e Fufia ${ }^{207}$ estenderam o direito à obnuntiatio a todos os magistrados. É interessante notar a data destas leis: cerca de 150 a.C.: o ano desta tentativa de coibição de iniciativas tribunícias leva a crer que nas duas décadas anteriores aos Gracos tribunos se fizeram notar, não só por obstruir o recrutamento de soldados (que realizaram diversas vezes), mas possivelmente também por outras iniciativas polêmicas de que, silente Lívio, não temos registro ${ }^{208}$.

O último e mais drástico reduto da oposição à ação tribunícia era o senatus consultum ultimum (mais propriamente: senatus consultum de re publica defenda), a decretação de um efetivo estado de exceção em Roma, em que a defesa da cidade era entregue pelo Senado a um indivíduo, que tinha liberdade para exercer qualquer ato em nome da proteção da res publica. A decretação do primeiro senatus consultum ultimum levou à morte de Caio Graco e seus seguidores em 121 a.C..

Lúcio Cornélio Sila, em reação às exponenciais mudanças ocasionadas por atividade tribunícia nas décadas anteriores - não só às ações de populares, mas também à iniciativa do mariano Públio Sulpício Rufo, que havia agido no concilium para subtrair o comando da guerra contra Mitrídates de Sila em favor de Mário, levando Sila a marchar sobre Roma - , restringiu o poder e o prestígio do tribunado da plebe na reforma constitucional que realizou durante sua ditadura. Não se sabe com certeza de que formas Sila tolheu os poderes tribunícios, exceto uma: a qualquer indivíduo que fosse eleito ao tribunado ficou vedado seguir o cursus honorum, isto é, assumir qualquer outra magistratura no decurso de sua

\footnotetext{
207 A lex Aelia e a lex Fufia, duas leis do segundo século objetivando limitar a promulgação de leis perniciosas com a imposição de restrições religiosas, tiveram parte de suas provisões revogadas pelo tribuno Públio Clódio Pulcro em 58 a.C.. As leis afirmaram o poder de um magistrado ou áugure, na ocasião da propositura de leis por outrem em comitia - notadamente tribunos observar os céus e obnuntiare. Segundo Taylor, as leis conferiram (ou reafirmaram) o direito do tribuno fazer o mesmo ao legislarem outros magistrados; mas a importância da obnuntiatio para o tribuno é reduzida, haja vista o mais contundente direito ao veto que possui (1962, p. 23ss.). Para uma discussão da potência relativa da obnuntiatio e da intercessio após Bíbulo e do teor da reforma clodiana, vide Taylor, supra; e Mitchell, 1986, 172ss.
}

208 Taylor, 1962, pp. 22ss. 
carreira política. O poder dos tribunos de propor legislação parece ter sido reduzido, senão eliminado, pois o concilium plebis aparentemente teve seu escopo de ação restrito à eleição dos magistrados plebeus. Quanto à intercessio, as fontes são conflitantes, mas parece ter também havido restrição ao seu uso. O ius auxilii se manteve ${ }^{209}$.

Sila, no dizer de Syme, reduziu o tribunado à impotência e à desonra: representantes de famílias ilustres só voltariam a se candidatar à magistratura após a abolição em 75 a.C. da proibição de ex-tribunos seguirem no cursus honorum e do retorno da magistratura a seus poderes anteriores à reforma, no consulado de Pompeu e Crasso ${ }^{210}$. A partir de então, o tribunado voltou a ser um dos instrumentos privilegiados da luta política do período, e a instância de inovação por excelência ${ }^{211}$.

\section{O tribuno no declínio da República}

O diagnóstico de Sila do tribunado como fonte de grandes males no último século da República foi repetido por muitos historiadores desde então, que criticam tribunos populares por terem minado as instituições republicanas, desestabilizando a organização constitucional romana a um grau irremediável, precipitando o início do Principado.

O processo comumente referido como "fim da República" é um evento histórico de demarcação controversa na doutrina romanista; momentos apontados como possíveis termos são diversos, do primeiro Triunvirato à denominação oficial de Otávio como princeps, ou mesmo à abolição da eleição das magistraturas por Tibério. É necessário apontar que a mera dominação pessoal do governo, se transitória, não era de forma alguma inconsistente com o mos maiorum. No geral, os grandes generais

\footnotetext{
209 Grunt, 1995, p. 23.

210 Syme, 1963, p. 55.

211 David, 1993, p. 50.
} 
que no último século da República se sucederam no papel de princeps (lato sensu, "primeiro homem de Roma", não na acepção do termo pós-Augusto) obtiveram o comando de seus exércitos a princípio de forma legal; e o destaque político de indivíduos por sua excelência militar estava de fato no cerne dos valores da sociedade romana ${ }^{212}$. A simples existência de comandantes de grande calibre não explica a crise, embora dela tenham sido a força motriz por excelência.

Da mesma forma, a atuação de diversos tribunos neste período, ainda que prolífica, não é por si só uma explicação para a erosão dos órgãos políticos tradicionais. É decerto simplista e algo elitista a atribuição de culpa aos tribunos da plebe - e, por extensão, às massas ditas facilmente persuadidas de que se aproveitavam para passar suas propostas no concilium - pela derrocada da Roma republicana, como será examinado a seguir. Não se pode ter a intenção de, com o presente breve exame, realizar uma investigação compreensiva das razões, múltiplas e complexas, da transformação da República em Principado; foge inclusive ao escopo de um limitado estudo sobre o tribunado analisar as esferas econômicas e sociais da crise, ainda que a atividade tribunícia tenha tido profundos efeitos em ambas. Feita esta ressalva, cumpre manter o foco nas mudanças políticas do período em tela em que tribunos foram diretamente implicados.

É necessário conceder, primeiramente, que uma consequência imprevisível geralmente atribuída ao tribunado dos Gracos de fato teve papel central no processo de declínio da República: a divisão interna irreconciliável da elite senatorial.

O Senado até então tinha uma tradição de concordia interna notável: no geral, a resolução de disputas políticas entre membros da elite se dava em discussões e embates não-violentos, o que levava a nobilitas a apresentar uma frente razoavelmente coesa em conflitos com interesses de

\footnotetext{
212 Rosenstein \& Morstein-Marx, 2006, loc. 10251ss.
} 
outras nações, ou mesmo de coletividades romanas como a plebs e os equites. Todavia, esta coesão deixou de existir após a lex agraria de Tibério e, principalmente, a crise que a sucedeu: "this explosion divided the elite and threw its parts back upon the two civic power-bases in Rome - Senate and People - and upon their corresponding, now often opposing legitimating principles"213.

O tribunado dos Gracos e seus assassinatos, expressão superlativa do descompasso entre a vontade da elite e as necessidades da plebe, revelou a crise de legitimidade inerente ao conflito de interesses entre o Senado e o povo de Roma. A rixa entre os que alegavam defender um ou outro, sempre em nome da res publica, constituiria o arcabouço de diversas disputas, por vezes violentas, que assolariam a elite senatorial nas décadas seguintes. Segundo Meier, este surgimento de oposições demasiadamente ferrenhas para serem conciliadas na disputa política tradicional tornou as instituições romanas - que em essência dependiam do equilíbrio entre elas garantido pelo ideal de concordia — vulneráveis a toda sorte de abuso, e elas começaram a se desmantelar.

Meier ressalta o notável apreço que todos os atores envolvidos nos conflitos deste período aparentavam ter pela ordem constitucional romana nos momentos em que a transformavam: sem exceção, as principais figuras revolucionárias alegavam agir em defesa dos princípios basilares da res publica. Houve clara fragmentação da legitimidade: elas não agiam em momento algum contra - por exemplo, no caso de César - a instituição do Senado, e sim em prol do Senado em abstrato contra senadores persuadidos pela facção de Pompeu a agir erroneamente e a distorcer seu dever político para com Roma ${ }^{214}$.

Gruen tem uma perspectiva peculiar: para ele, o fracasso das instituições republicanas diagnosticado em retrospecto pela historiografia

\footnotetext{
213 Rosenstein \& Morstein-Marx, 2006, loc. 10408. 214 Meier, 1996, p. 37ss..
} 
não significava à época uma derrocada sem remédio. O Senado demonstrou notável adaptabilidade ao conseguir lidar com as consequências das ações dos grandes generais, até César. De acordo com Gruen, portanto, a guerra civil levou ao fim da República, e não o inverso ${ }^{215}$.

Muito embora seja fundamental o questionamento que Gruen defende da perspectiva tradicional do declínio da República, MorsteinMarx e Rosenstein discordam de suas conclusões, apontando que o progressivo enfraquecimento das instituições romanas é evidente pela sua dificuldade em se adaptar às consequências da guerra civil entre César e Pompeu após ter, décadas antes, sobrevivido à de Sila e Mário.

Não é possível atribuir tal crise em grande parte, como fez a historiografia clássica, ao crescimento do império: tal explicação parte da premissa (obviamente questionável) de que o governo de tamanha extensão só poderia ser administrado por um déspota. Não há prova de que as relativamente mais democráticas instituições republicanas seriam incapazes de deliberar sobre um número maior de províncias ${ }^{216}$.

Uma das causas comumente identificadas do declínio da República em que há inegável atuação do tribunado é a constituição dos chamados "exércitos privados": soldados com maior devoção ao general que servem do que a Roma. Tribunos como Públio Sulpício Rufo ${ }^{217}$ e Caio Escribônio Curião ${ }^{218}$, agindo em prol de comandantes de calibre (Mário e César, respectivamente), foram essenciais para a obtenção e manutenção do comando de guerras para seus patronos; e, findas suas guerras, generais

\footnotetext{
215 Gruen, 1995, p. 504.

216 Rosenstein \& Morstein-Marx, 2006, loc. 10332ss.

217 Sobre as alianças e conflitos políticos que informaram o tribunado de Públio Sulpício Rufo, vide Lintott, 1971, pp. 442-453.

218 Para uma análise do tribunado de Curião refutando a perspectiva tradicional de que era um lacaio de César e ressaltando suas qualidades como político independente, vide Lacey, 1961, pp. 318-329.
} 
utilizavam seus aliados tribunos para legislar no concilium plebis concedendo terras para os veteranos ${ }^{219}$.

A doutrina aponta como origem dos "exércitos privados" as reformas militares de Caio Mário em 107 a.C.: Mário, objetivando aumentar o efetivo disponível para a guerra contra Jugurta, eliminou o requisito censitário para participação no exército, recrutando pela primeira vez entre os capite censi (literalmente aqueles que eram "contados por cabeça" no censo; sem propriedade). Entende-se que a presença dos capite censi nas legiões teria resultado nesta devoção porque eles dependiam do poderio político de seu comandante para lhes facilitar a concessão de terras após o término da guerra em questão ${ }^{220}$; assim, estariam dispostos a seguir o general mesmo quando este agisse contra os interesses da res publica, como por exemplo as marchas sobre Roma de Sila e César. No entanto, não há qualquer prova de que o recrutamento de capite censi criado por Mário foi de fato realizado por outros generais, ou de qualquer exército que tenha sido persuadido a agir pela promessa de terras (nota-se que a possibilidade de espólios regulares de guerra, é claro, sempre foi um dos maiores atrativos para o serviço militar). Além disso, é relevante que tanto os soldados de Sila quanto os de César acreditavam estar marchando em prol da res publica, para salvá-la da ação de senadores inescrupulosos que a ameaçavam. De qualquer forma, deve-se notar que a utilização destes "exércitos privados" só se verificou a partir da década de 80 a.C.; não se deve, portanto, arrolá-los entre as primeiras causas da crise que já então se avultava $^{221}$.

\footnotetext{
219 A ação tribunícia beneficiando veteranos tinha a relevante consequência, primeiramente demonstrada no caso de Saturnino, de que estes se juntavam em massa ao contingente popular que defendia a pessoa do tribuno contra a hostilidade da elite. Nas palavras de Badian: "It is unlikely that Saturninus intended to use violence for political ends (...). But the Optimates used force against his corn law, hoping that they could deal with him as they had with the Gracchi. Saturninus learnt the lesson and used the Marian veterans to full effect." (1962, p. 218)

220 Diz Mommsen sobre o legionário após as reformas marianas: "His only home was the camp, his only science war, his only hope the general — what this implied is clear.” (1894c, p. 461).

${ }^{221}$ Rosenstein \& Morstein-Marx, 2006, loc. 10307ss.
} 
Há percepção geral, algo distorcida, de que as últimas décadas da República foram repletas de grandes reformas legislativas de iniciativa tribunícia. Ainda que inegável o papel de tribunos nas inovações do período, fato é que outros magistrados — principalmente cônsules — também introduziram importantes reformas. Em realidade, Gruen aponta que as reformas legislativas de que há registro das prolíficas últimas décadas da República - especialmente relativas aos tribunais, ao Direito Penal, à administração da cidade, e a crimes eleitorais — não foram sequer em sua maioria obra de tribunos, ou ainda somente propostas por indivíduos populares. Menos de um terço destas leis foram obra de tribunos; de especial nota foi o furor legislativo de Clódio em seu tribunado e de César em seu consulado.

Segundo Gruen, adquirindo-se consenso sobre a necessidade de uma mudança aceitável em Roma, ela acabava no geral por ser executada — tanto por magistrados optimates quanto por populares - por vezes com uma disputa acirrada pelo crédito pela mesma, como no conflito entre o cônsul Lúcio Calpúrnio Piso e o tribuno Cornélio pela lei de suborno eleitoral de 57 a.C. ${ }^{222}$. Sequer se podem atribuir a furores tribunicii, portanto, as frequentes inovações legislativas e consequente instabilidade normativa do declínio da República.

Em resumo, como diz Taylor, a transformação do tribunado em instrumento de revolução neste período foi um sintoma, não a causa do declínio da República ${ }^{223}$. A turbulenta atividade tribunícia era reflexo direto dos problemas sistêmicos de Roma, e nela se viam representados todos os interesses conflitantes em jogo: os objetivos que almejavam os generais, os optimates e o povo eram revelados e disputados no dia-a-dia do tribuno no Senado e na Assembleia da Plebe.

\footnotetext{
222 Para uma análise detalhada da legislação das últimas décadas da República nos campos mencionados, vide Gruen, 1995, pp. 211-259.

${ }^{223}$ Taylor, 1962, p. 27.
} 
A figura do tribuno, já então não mais emblema da plebs e sim de todo o populus, tanto elite quanto multidão despossada, acabou por encarnar em essência a República — seus conflitos, contradições e idiossincrasias - e, como ela, jamais foi tão explosiva, controversa e brilhante quanto em seu fim. 


\section{Conclusão}

A história da evolução do tribunado da plebe é o maior testamento à elasticidade da ordem constitucional romana. É admirável ter a ordem política se adaptado com sucesso às diversas demandas do conflito entre as ordens em seus vários estágios com a criação e mutação de instrumentos para efetuar as mudanças necessárias em cada um deles.

O estudo do conflito das ordens e dos institutos a ele ligados, principalmente o tribunado, encontra sério óbice na tendenciosa tradição analítica; faz-se necessário tentar distinguir nas entrelinhas as reais demandas sociais e as possivelmente louváveis intenções de indivíduos controversos; ainda assim, é relevante o exame da historiografia romana em seus próprios méritos por, sendo o Direito público romano essencialmente costumeiro, ter sido ela durante toda a República fonte de precedentes mesmo fabricados e fictícios - para a ação de atores políticos.

Não se pode precisar a origem da distinção entre patrícios e plebeus, ou o momento exato em que se unificaram as demandas da plebs despossada e as da elite plebeia; mas findaram estas por suplantar aquelas, e a narrativa tradicional do conflito das ordens finda em 287 a.C. com a efetividade plena das resoluções da Assembleia da Plebe perante todo o povo romano. As conquistas da secessio, afinal, acabaram paradoxalmente sendo o instrumento que divorciou quase que por completo os institutos de proteção da plebs de sua efetiva defesa, posto que foram dominados pela elite plebeia. Seguiu-se uma narrativa de disputa de ricos contra pobres, em que estes - ao contrário da elite plebeia nos séculos anteriores obtiveram parcos sucessos, e estes em sua maioria por obra de tribunos que se destacaram no cargo por advogarem a causa dos menos favorecidos. 
O mos maiorum romano se construía na constante dialética entre o conformismo e a transgressão ${ }^{224}$; assim também os poderes tribunícios, principalmente o veto e a atuação no concilium plebis, foram gradualmente enfrentando e expandindo seus próprios limites nas mãos de tribunos que enxergaram no potencial inerente à magistratura a solução para a reforma das piores falhas das instituições romanas.

É inegável que a evolução dos poderes do tribunado — cada vez mais intrinsecamente ligado à sua função pública e à manutenção da res publica, sem se separar de fato de sua função original de defensor do povo - criou, nas palavras de Badian, "a constitutional monstrosity"225 na antítese que contrapunha a proteção conferida por seus poderes defensivos e sua prática ofensiva cada vez mais irrestrita.

Os privilégios tribunícios foram talvez abusados por indivíduos ambiciosos e de acume político: não, eu diria, pelos mais explosivos populares com programas de reforma, mas sim por optimates que, no bom espírito da concordia republicana, também se fizeram representar no colegiado tribunício e utilizaram a tribunicia potestas em prol de interesses senatoriais. É possível que se houvesse evitado a ocorrência de algumas das mais sérias crises constitucionais da República tardia se os optimates não tivessem representantes entre os tribunos.

Enfim, é inútil lamentar a crise institucional de Roma questionando as decisões dos atores envolvidos. Como disse Montesquieu: "Si César et Pompée avoient pensé comme Caton, d'autres auroient pensé comme firent César et Pompée"226; talvez o mesmo se possa dizer dos Gracos. O último século da República foi cenário para o fulgor e a derrocada da carreira de diversos romanos de brilhantismo inquestionável, e muitos deles

\footnotetext{
224 David, 1993, p. 60.

225 Badian, 1996, pp. 208ss..

226 Montesquieu, 1831, p. 103.
} 
engrandeceram o tribunado com suas ações audazes, quaisquer que tenham sido os interesses que representaram.

Caio Graco, em seus discursos lamentando a morte de seu irmão, famosamente dizia ao povo romano que a plebs de outrora defendera muito melhor seus direitos, e seus tribunos ${ }^{227}$. É impossível negar a força da secessio plebis, em que nasceu o tribuno; e é também inegável a fragilização da inviolabilidade tribunícia na República tardia. Ainda assim, com a devida vênia ao brilhante tribuno, discordo: Roma havia desde então crescido de sociedade agrária a império, e com ela suas instituições, e Tibério havia com efeito iniciado uma revolução, chamando de volta à política o povo que com os séculos dela havia se afastado; o levantar da voz de um tribuno popularis sequer era o clamor de milhares de plebeus despossados que afinal se fazia ouvir no concilium. O sacrifício das vidas dos seguidores de Tibério, mortos ao lhe servirem de escudo, honrou o lendário juramento sacro de 494 a.C.; os Gracos abriram caminho para a carreira de diversos tribunos que ousaram estender ao máximo os limites do mos maiorum em prol do povo e, assim, fizeram jus à essência do instituto do tribunado.

A figura do tribuno se apagou no Principado, como não poderia deixar de ser, haja vista a ordem política de que Augusto lançou mão para restaurar a res publica. Não havia mais lugar para um instituto de tamanho potencial revolucionário sob o princeps.

O tribunado foi uma criação essencialmente republicana, sem igual em qualquer outro governo desde então, em cujo bojo se vislumbra o testamento à sedição, à política e à genialidade que permitiram que os cidadãos daquela pequena cidade às margens do Tibre criassem um império que duraria por séculos.

227 Plutarco, Caio Graco, 3.3 (1965, p. 178). 


\section{Bibliografia}

ARANGIO-RUIZ, Vincenzo. Storia del Diritto Romano. $7^{\text {a }}$. edição. Napoli: Casa Editrice Dottore Eugenio Jovene, 2006. 456p.

BADIAN, Ernst. From the Gracchi to Sulla (1940-59). In: Historia: Zeitschrift für Alte Geschichte, Bd. 11, H. 2. 1962. p. 197 - 245.

. Tiberius Gracchus and the Beginning of the Roman Revolution. In: SCHWERDTFEGER, Stephan; ILCHMANN, Ute (Org.). Aufstieg und Niedergang der römischen Welt. $1^{\mathrm{a}}$ edição. Berlin: W. de Gruyter, 1972. p. $668-731$.

. Tribuni plebis and res publica. In: LINDERSKI, Jerzy (Org.). Imperium sine fine. $1^{\mathrm{a}}$ edição. Stuttgard: Steiner, 1996. p. 187-214.

BRINGMANN, Klaus. A History of the Roman Republic. $1^{\text {a }}$ edição. Cambridge: Polity Press, 2007. 358p.

BRUNT, P. A.. The Army and the Land in the Roman Revolution. In: The Journal of Roman Studies, Vol. 52. 1962. p. 69 - 86.

CÉSAR, Caio Júlio. A guerra civil. 1ª edição. São Paulo: Estação Liberdade, 1999. 309p.

CICERONIS, M. Tvlli. De Re Pvblica; De Legibvs; Cato Maior de Senectvte; Laelivs de Amicitia. 1 ${ }^{\mathrm{a}}$. edição. Oxford: Oxford University Press, 2006. 466p.

CICERO, Marcus Tullius. Defence Speeches. 2a . edição. Oxford: Oxford University Press, 2008a. 275p.

CICERO, Marcus Tullius. The Republic and The Laws. 2a . edição. Oxford: Oxford University Press, 2008b. 242p.

CORNELL, Tim J.. The Value of the Literary Tradition Concerning Archaic Rome. In: RAAFLAUB, Kurt A. (Org.). Social Struggles in Archaic Rome: New Perspectives on the Conflict of the Orders. 2a. edição. Oxford: Blackwell Publishing, 2005. p. $47-74$.

. The Beginnings of Rome. 9a edição. Oxon: Routledge, 2009. 507p.

DAVID, Jean-Michel. Conformismo e transgressione: A proposito del tribunato della plebe alla fine della repubblica romana. In: Studi Storici, anno 34, n. 1. 1993. p. $49-60$.

DE MARTINO, Francesco. Storia della costituzione romana, Vol. 1. 2a edição. Napoli: Casa Editrice Dottore Eugenio Jovene, 1972. 503p.

. Storia della costituzione romana, Vol. 2. 2a edição. Napoli: Casa Editrice Dottore Eugenio Jovene, 1973. 546p. 
DE SANCTIS, Gaetano. Storia dei Romani. Vol. 1. 1ª edição. Torino: Fratelli Bocca Editori, 1907. 484p.

DEVELIN, Robert. "Provocatio" and Plebiscites. Early Roman Legislation and the Historical Tradition. In: Mnemosyne, Vol. 31, Fasc. 1. 1978. p. $45-$ 60.

. The Integration of the Plebeian into the Political Order After 366 B.C.. In: RAAFLAUB, Kurt A. (Org.) Social Struggles in Archaic Rome: New Perspectives on the Conflict of the Orders. 2a . edição. Oxford: Blackwell Publishing, 2005. p. 293 - 311.

DIODORUS SICULUS, The Persian Wars to the Fall of Athens - books 11-14.34. Edição Kindle. Austin: University of Texas Press, 2010.

EDER, Walter. Augustus and the Power of Tradition: The Augustan Principate as Binding Link Between Republic and Empire. In: RAAFLAUB, Kurt A.; TOHER, Mark (Org.). Between Republic and Empire: Interpretations of Augustus and his Principate. London: University of California Press, 1993. p. $71-122$.

. The Political Significance of the Codification of Law in Archaic Societies: An Unconventional Hypothesis. In: RAAFLAUB, Kurt A. (Org.). Social Struggles in Archaic Rome: New Perspectives on the Conflict of the Orders. 2a . edição. Oxford: Blackwell Publishing, 2005. p. 239 - 267.

FINLEY, Moses I.. Política no mundo antigo. 1'a . edição. Lisboa: Edições 70, 1983. 175p.

FORSYTHE, Gary. A Critical History of Early Rome. 2a . edição. Berkeley: University of California Press, 2005. 400p.

GIORDANI, Mário Curtis. História de Roma. 14ª edição. Petrópolis: Vozes, 2001. 395p.

GOLDSWORTH, Adrian. Caesar - The Life of a Colossus. $2^{\mathrm{a}}$ edição. London: Phoenix, 2007. 696p.

GROSSO, Giuseppe. Lezioni di storia del Diritto Romano. 5a. edição. Torino: G. Giappichelli Editore, 1965. 527p.

GRUEN, Ernst. The Last Generation of the Roman Republic. $3^{\mathrm{a}}$ edição. Berkeley: University of California Press, 1995. 596p.

HILDINGER, Eric. Swords Against the Senate: The Rise of the Roman Army and the Fall of the Republic. 2a edição. Cambridge: Capo Press, 2003. 240p.

JEHNE, Martin. Romma nell'età della repubblica. 2a . edição. Bologna: Mulino, 2008. 156p.

KEAVENEY, Arthur. Sulla: The Last Republican. 2a . edição. New York: Routledge, 2005. 233p. 
LACEY, W. K. The Tribunate of Curio. In: Historia: Zeitschrift für Alte Geschichte, Bd. 10, H. 3. 1961. p. 318 - 329.

LAST, Hugh. The Servian Reforms. In: The Journal of Roman Studies, Vol. 35. 1945. p. $30-48$.

LINDERSKI, Jerzy. Religious Aspects of the Conflict of the Orders: The Case of confarreatio. In: RAAFLAUB, Kurt A. (org.) Social Struggles in Archaic Rome: New Perspectives on the Conflict of the Orders. 2a ${ }^{\mathrm{a}}$. edição. Oxford: Blackwell Publishing, 2005. p. 223 - 238.

LINTOTT, Andrew W. The Tradition of Violence in the Annals of the Early Roman Republic. In: Historia: Zeitschrift für Alte Geschichte, Bd. 19, H. 1. 1970. p. $12-29$.

. The Tribunate of P. Sulpicius Rufus. In: The Classical Quarterly, New Series, Vol. 21, N. 2. 1971. p. $442-453$.

. Electoral Bribery in the Roman Republic. In: The Journal of Roman Studies, Vol. 80. 1990. p. 1 - 16.

. The Constitution of the Roman Republic. $3^{\mathrm{a}}$ edição. Oxford: Oxford University Press, 1999. 297p.

LIVY, Titus. The Rise of Rome - books 1-5. Oxford: Oxford University Press, 1998. 372p.

KONRAD, C. F. From the Gracchi to the First Civil War. In: ROSENSTEIN, Nathan; MORSTEIN-MARX, Robert (Org.). A Companion to the Roman Republic. Edição Kindle. Oxford: Blackwell Publishing, 2006.

MAGDELAIN, André. Remarques sur la Perduellio. In: Historia: Zeitschrift für Alte Geschichte, Bd. 22, H. 3. 1973. p. 405 - 422.

MACHIAVELLI, Niccolò. Discursos sobre a primeira década de Tito Livio. 1 ${ }^{\text {a }}$. edição. São Paulo: Martins Fontes, 2007. 471p.

MAZZARINO, Santo. Dalla monarchia allo stato republicano. $2^{\mathrm{a}}$ edição. Milano: Biblioteca Universale Rizzoli, 2001. 270p.

MEIER, Christian. Caesar. 2a . edição. London: Fontana Press, 1996. 513p.

MILLAR, Fergus. The Crowd in the Late Roman Republic. 4a. edição. Ann Arbor: University of Michigan Press, 1998. 236p.

MITCHELL, Richard E. The Definition of patres and plebs: An End to the Struggle of the Orders. In: RAAFLAUB, Kurt A. (Org.). Social Struggles in Archaic Rome: New Perspectives on the Conflict of the Orders. $2^{\mathrm{a}}$ edição. Oxford: Blackwell Publishing, 2005. p. 128 - 167.

MITCHELL, T. N.. The Leges Clodiae and obnuntiatio. In: The Classical Quarterly, New Series, Vol. 36 (1986). p. 172 - 176.

MOMIGLIANO, Arnaldo. An Interim Report on the Origins of Rome. In: The Journal of Roman Studies, Vol. 53 (1963). p. 95 - 121. 
- Quarto contributo alla storia degli studi classici e del mondo antico. $1^{\text {a }}$. edição. Roma: Edizioni di storia e letteratura, 1969. 749p.

. The Rise of the plebs in the Archaic Age of Rome. In: RAAFLAUB, Kurt A. (Org.). Social Struggles in Archaic Rome: New Perspectives on the Conflict of the Orders. $2^{\text {a }}$ edição. Oxford: Blackwell Publishing, 2005. p. $168-184$.

MOMMSEN, Theodor. The History of Rome, Vol. 1. $1^{\text {a }}$ edição. London: Richard Bentley \& Son, 1894a. 508p.

. The History of Rome, Vol. 2. $1^{\text {a }}$ edição. London: Richard Bentley \& Son, 1894b. 525p.

. The History of Rome, Vol. 3. $1^{\text {a }}$ edição. London: Richard Bentley \& Son, 1894 c. $547 \mathrm{p}$.

MONTESQUIEU, Charles-Louis de Secondat, Baron de. Considérations sur les causes de la grandeur des romains et de leur décadence. $1^{\text {a }}$ edição. Paris: P. Pourrat Frères Éditeurs, 1831. 346p.

MORSTEIN-MARX, Robert. Mass Oratory and Political Power in the Late Roman Republic. $1^{\text {a }}$ edição. Cambridge: Cambridge University Press, 2004. 313p.

MOURITSEN, Henrik. Plebs and Politics in the Late Roman Republic. Edição Kindle. Cambridge: Cambridge University Press, 2001.

MOUSOURAKIS, George. A Legal History of Rome. $1^{\text {a }}$ edição. New York: Routledge, 2007. 282p.

NIEBUHR, Barthold. The Roman History, Vol. 1. $1^{\text {a }}$ edição. London: C. and J. Rivington, 1827. 480p.

OAKLEY, Stephen. The Early Republic. In: FLOWER, Harriet I. (Org.). The Cambridge Companion to the Roman Republic. $2^{\mathrm{a}}$ edição. New York: Cambridge University Press, 2004. p. 15 - 30.

PARENTI, Michael. The Assassination of Julius Caesar: A People's History of Ancient Rome. $2^{\mathrm{a}}$ edição. New York: The New Press, 2004. 276p.

PLUTARCH. Makers of Rome. $1^{\text {a }}$ edição. London: Penguin Books, 1965. 366p.

RAAFLAUB, Kurt A. The Conflict of the Orders in Archaic Rome: A Comprehensive and Comparative Approach. In: RAAFLAUB, Kurt A. (Org.). Social Struggles in Archaic Rome: New Perspectives on the Conflict of the Orders. $2^{\mathrm{a}}$ edição. Oxford: Blackwell Publishing, 2005a. p. 1 - 46.

. From Protection and Defense to Offense and Participation: Stages in the Conflict of the Orders. In: RAAFLAUB, Kurt A. (Org.). Social Struggles in Archaic Rome: New Perspectives on the Conflict of the Orders. $2^{\mathrm{a}}$ edição. Oxford: Blackwell Publishing, 2005b. p. 185 - 222. 
. Between Myth and History: Rome's Rise from Village to Empire (the Eighth Century to 264). In: ROSENSTEIN, Nathan; MORSTEINMARX, Robert (Org.). A Companion to the Roman Republic. Edição Kindle. Oxford: Blackwell Publishing, 2006.

RICHARD, Jean-Claude. Patricians and Plebeians: The Origins of a Social Dichotomy. In: RAAFLAUB, Kurt A. (Org.). Social Struggles in Archaic Rome: New Perspectives on the Conflict of the Orders. 2a ${ }^{\text {a }}$ edição. Oxford: Blackwell Publishing, 2005. p. 107 - 127.

RIDLEY, Ronald T. Leges Agrariae: Myths Ancient and Modern. In: Classical Philology, Vol. 95, N. 4 (2000). p. 459 - 467.

ROSENSTEIN, Nathan; MORSTEIN-MARX, Robert. The Transformation of the Republic. In: ROSENSTEIN, Nathan; MORSTEIN-MARX, Robert (Org.). A Companion to the Roman Republic. Edição Kindle. Oxford: Blackwell Publishing, 2006.

ROWLAND JR., Robert J.. C. Gracchus and the Equites. In: Transactions and Proceedings of the American Philological Association, Vol. 96. 1965. p. $361-373$.

RUNDELL, W. M. F.. Cicero and Clodius: The Question of Credibility. In: Historia: Zeitschrift für Alte Geschichte, Bd. 28, H. 3 (1979) p. 301 - 328.

SEAGER, Robin. 'Populares' in Livy and the Livian Tradition. In: The Classical Quarterly, New Series, Vol. 27, N. 2 (1977). p. 377 - 390.

SCULLARD, Howard H. From the Gracchi to Nero. 5a edição. New York: Routledge, 2007. 500p.

SHELTON, Jo-Ann. As The Romans Did - A Sourcebook in Roman Social History. 2a edição. Oxford: Oxford University Press, 1998. 483p.

SPAETH, Barbette Stanley. The Goddess Ceres and the Death of Tiberius Gracchus. In: Historia: Zeitschrift für Alte Geschichte, Bd. 39, H. 2 (1990) p. $182-195$.

STAVELEY, E. Stuart. Provocatio during the Fifth and Fourth Centuries B.C.. In: Historia: Zeitschrift für Alte Geschichte, Bd. 3, H. 4. 1955. p. 412 -428 .

SYME, Ronald. Ten Tribunes. In: The Journal of Roman Studies, Vol. 53 (1963). p. $55-60$.

. The Roman Revolution. $2^{\mathrm{a}}$ edição. Oxford: Oxford University Press, 2002. 568p.

TACITUS. The Complete Works of Tacitus. $1^{\mathrm{a}}$ edição. New York: Random House, 1942.

TAYLOR, Lily Ross. Forerunners of the Gracchi. In: The Journal of Roman Studies, Vol. 52 (1962). p. 19 - 27. 
TATUM, W. Jeffrey. The Patrician Tribune: Publius Clodius Pulcher. 1'. edição. Chapel Hill: University of North Carolina Press, 1999. 365p.

TORELLI, Mario. The Topography and Archaeology of Republican Rome. In: ROSENSTEIN, Nathan; MORSTEIN-MARX, Robert (Org.). $A$ Companion to the Roman Republic. Edição Kindle. Oxford: Blackwell Publishing, 2006.

VISHNIA, Rachel F.. The "Transitio ad plebem" of C. Servilius Geminus. In: Zeitschrift für Papyrologie und Epigraphik, Bd. 114 (1996a) p. 289 298.

. State, Society and Popular Leaders in Mid-Republican Rome 241-167 BC. 1 ${ }^{\mathrm{a}}$. edição. New York: Routledge, 1996b. 264p.

VON UNGERN-STERNBERG, Jürgen. The Formation of the "Annalistic Tradition": The Example of the Decemvirate. In: RAAFLAUB, Kurt A. (Org.) Social Struggles in Archaic Rome: New Perspectives on the Conflict of the Orders. 2a. edição. Oxford: Blackwell Publishing, 2005a. p. 75 - 97.

. The End of the Conflict of the Orders. In: RAAFLAUB, Kurt A. (Org.) Social Struggles in Archaic Rome: New Perspectives on the Conflict of the Orders. 2a. edição. Oxford: Blackwell Publishing, 2005b. p. 312 332.

WISEMAN, Timothy P.. New Men in the Roman Senate: 139 B.C. - A.D. 14. 1'a edição. London: Oxford University Press, 1971. 325p.

. The Myths of Rome. $2^{\mathrm{a}}$. edição. Exeter: University of Exeter Press, 2008. 390p.

YAKOBSON, Alexander. Secret Ballot and Its Effects in the Late Roman Republic. In: Hermes, Bd. 123. H. 4. 1995. p. 426 - 442. 


\section{Índice remissivo}

aediles plebis: vide edis plebeus

acervo da plebe 25,60

apelo à plebe: vide provocatio

ager publicus 22, 43, 49, 50, 56, 64

ambitus 50, 50n

auspicia $16,47 \mathrm{n}$

Assembleia da Plebe 24, 41, 42, 42n, 43-54, 71

auctoritas patrum $46,47,47 \mathrm{n}$

Aventino 13, 23n, 25, 35

capite censi 75

Catilina, Lúcio Sérgio 38, 54

censores 17

Ceres 23n, 24, 25, 35, 38

Cícero, Marco Túlio 13, 26, 34n, 37, 39, 39n, 41, 44, 54, 66, 69

cerramento do patriciado: vide serrata

clientela 14, 14n, 17, 46

Clódio Pulcro, Públio 30n, 34n, 38, 39, 39n, 42, 54,

69, 70n, 76

coercendi potestas 36

comitia $25 \mathrm{n}$

curiata $15,15 \mathrm{n}, 45$

centuriata 50, 56, 60n

tributa 46,48

Comitium 21, 36

concilium plebis: vide Assembleia da Plebe

concordia 42, 44, 72, 73, 79

confarreatio 62

consulado

demanda da plebe pelo 19

cônsules plebeus 18

primeiros cônsules 19, 22

vedação de ex-tribunos ao 31, 32

ius auxilii contra cônsules 36,36n

contiones 29, 29n, 41, 42, 42n, 49, 68

cursus honorum 30, 30n

decenvirato: vide Lei das XII Tábuas

ditador 22, 35n, 40, 47

dívidas: vide endividamento

Druso, Marco Lívio 38, 38n

eleição

de tribunos e edis $24,29 n$

de magistrados 50

edis plebeus $24,24 \mathrm{n}, 52$

equites $17,51,51 \mathrm{n}, 52,66$

endividamento $22,23,24$

exército $12,16,16 \mathrm{n}, 17,18,23,27,51,75$

fasti consulares $18,18 \mathrm{n}$

flamen dialis 62,65

Flamínio, Caio 33n, 51, 51n, 66

Gracos 11, 26, 33n, 67, 72, 73, 75n

Tibério Graco 28n, 31, 37, 38, 39, 42, 43, $51,67,68,80$

$$
\text { Caio Graco 35, 37, 38, 39, 51, 52, 70, } 80
$$

imperium 29,39

intercessio 27, 27n, 29, 36, 40-45, 69, 70n

interrex 16,65

inviolabilidade tribunícia: vide sacrosanctitas

ius auxilii 23n, 27, 29, 30, 33, 35, 36, 42n, 60n, 71 ius conubii 13, 56, 57, 58, 61, 62

Júnio Bruto, Lúcio 19

Júlio César, Caio 19n, 29, 29n, 37, 38, 39, 40, 41, $42,44,45,51,67,73,74,75,76,79$

lectio senatus 17,18

Lei das XII Tábuas 13, 24, 53, 55-63

leis escritas 25, 60

leges agrariae 43, 44, 49, 50, 51, 51n, 66, 73, 75

leges Liciniae-Sextiae 31, 46, 51n

leges Valeriae-Horatiae 26, 46, 59, 60, 62

lex Hortensia 24, 31, 46, 47, 48, 48n, 62, 65

lex Icilia de Aventino Publicando 46n, 56, 56n

Lívio, Tito; vide tradição analítica

magister populi $20 \mathrm{n}$

Mário, Caio 36n, 44, 45, 50, 70, 74, 75

mos $11,43,79,80$

nехит 22, 23n, 61, 66

obnuntiatio 29, 29n, 70

optimates $11,34,36,39,43,44,54,58,67-80$

ordo equester: vide equites

outsiders $15 \mathrm{n}, 38$

patriciado

origem 12-17

patres $15,15 \mathrm{n}, 17,62$

cerramento do: vide serrata

perduellio 36,52

plebe

composição 13-17

distinção entre patrícios e 13-20

casamento com patriciado: vide ius conubii plebs qua plebs 17, 19, 22, 23, 28, 66

identidade religiosa: vide religião

acesso ao consulado: vide consulado

secessão: vide secessio

juramento da: vide sacrosanctitas

plebeus no decenvirato $56-59$

plebiscitos 33n, 46, 47, 60, 65

Pompeu Magno, Cneu 29, 41, 44, 45, 71, 73, 74

populares $11,33,37-39,42-44,58,67-80$

praetor maximus/minor $22 \mathrm{n}$

Principado 31, 34, 35, 71, 72, 80

provocatio $13,29 \mathrm{n}, 52,53,54,57,60$

quaestiones 52

realeza; vide reis

reductio ad sacra 20

religião

auspícios: vide auspicia

ligação entre política e 16

ligação entre Direito e 60

plebeia $14,23 n, 25$

plebeus nos cargos sacerdotais 15, 64, 65

rex sacrorum: vide rex sacrorum

obstrução religiosa de leis: vide obnuntiatio

Regia 21

reis

caráter lendário 9

reis plebeus $1,15 \mathrm{n}, 21$

reis etruscos $15 \mathrm{n}$

Rômulo 13 


\section{Numa Pompílio 15}

Sérvio Túlio 13, 14, 15, 25n

Tarquínio Prisco 15

Tarquínio, o Soberbo 19, 21

fim da realeza 19-22

pretensões à realeza: vide tiranicídio

rex: vide reis

rex sacrorum 20, 62

sacer 35

sacrosanctitas 24, 35-40, 44, 80

Saturnino, Lúcio Apuleio 30, 37, 39, 52, 75n

secessio 12, 14, 16n, 17, 18, 23-26, 47, 57, 78

Senado

admissão de plebeus ao 15,16

privilégio hereditário de patrícios ao 16

escolha de senadores: vide lectio senatus

como órgão inicialmente ad hoc 17

conflito com últimos reis 21

convocação do por tribunos 29

tratamento de tribunos pelo $30,30 \mathrm{n}$

admissão de tribunos ao 32, 33, 66, 67

competência 49

admissão de equites 53

crise de legitimidade do 73, 74, 75

senatus consultum ultimum $39,54,70$

Sila Félix, Lúcio Cornélio 32n, 34, 40, 41, 52, 58, 70, 71, 74, 75

serrata del patriziato $15 \mathrm{n}, 18-20,63$

tiranicídio 20, 21, 37, 37n, 38n, 69

tribunado da plebe

criação $23-26$

poderes $26-54$

princípios $28,43,44$

prevalência de nobres no $28,31,32,34$,

$34 \mathrm{n}, 65,66,67$

novi homines tribunos $28,29,66$

restrições à tribunicia potestas 30, 30n, 40, $41,43,44$

no cursus honorum 30-31, 65, 70

restrições ao por Sila $34,70,71$

oposição ao recrutamento $33,36,37,51$

utilização pelos generais 44, 45, 70, 75, 76

tribunicia potestas de Augusto 34, 35

tribunos consulares $31 \mathrm{n}$

tradição analítica

problemas: 10-13

sobre origem de patrícios e plebeus 13

sobre fim da realeza 19-20

sobre secessio 23-24

sobre origem do tribunado 27

sobre populares 38

sobre o decenvirato 55-60

transitio ad plebem $18 \mathrm{n}, 33 \mathrm{n}$

veto tribunício; vide intercessio

voto secreto $50,50 \mathrm{n}$ 